\title{
Aquatic Sciences \\ Niche partitioning between invasive and native corixids (Hemiptera, Corixidae) in south-west Spain \\ --Manuscript Draft--
}

\begin{tabular}{|c|c|c|}
\hline Manuscript Number: & \multicolumn{2}{|l|}{ AQSC-D-15-00119R3 } \\
\hline Full Title: & \multicolumn{2}{|c|}{$\begin{array}{l}\text { Niche partitioning between invasive and native corixids (Hemiptera, Corixidae) in } \\
\text { south-west Spain }\end{array}$} \\
\hline Article Type: & \multicolumn{2}{|l|}{ Research Article } \\
\hline Keywords: & \multicolumn{2}{|c|}{ Invasive species, Corixidae, Trichocorixa, Sigara, Stable isotopes, Niche partitioning } \\
\hline Corresponding Author: & \multicolumn{2}{|l|}{$\begin{array}{l}\text { Cristina Coccia } \\
\text { Doñana Biological Station-CSIC } \\
\text { Sevilla, SPAIN }\end{array}$} \\
\hline \multicolumn{3}{|l|}{$\begin{array}{l}\text { Corresponding Author Secondary } \\
\text { Information: }\end{array}$} \\
\hline Corresponding Author's Institution: & \multicolumn{2}{|l|}{ Doñana Biological Station-CSIC } \\
\hline \multicolumn{3}{|l|}{$\begin{array}{l}\text { Corresponding Author's Secondary } \\
\text { Institution: }\end{array}$} \\
\hline First Author: & \multicolumn{2}{|l|}{ Cristina Coccia } \\
\hline \multicolumn{3}{|l|}{ First Author Secondary Information: } \\
\hline \multirow[t]{9}{*}{ Order of Authors: } & \multicolumn{2}{|l|}{ Cristina Coccia } \\
\hline & \multicolumn{2}{|l|}{ Brian Fry } \\
\hline & \multicolumn{2}{|l|}{ Francisco Ramírez } \\
\hline & \multicolumn{2}{|l|}{ Luz Boyero } \\
\hline & \multicolumn{2}{|l|}{ Stuart Bunn } \\
\hline & \multicolumn{2}{|l|}{ Carmen Diz-Salgado } \\
\hline & \multicolumn{2}{|l|}{ Mark Walton } \\
\hline & \multicolumn{2}{|l|}{ Lewis Le Vay } \\
\hline & \multicolumn{2}{|l|}{ Andy Green } \\
\hline \multicolumn{3}{|c|}{ Order of Authors Secondary Information: } \\
\hline \multirow[t]{2}{*}{ Funding Information: } & $\begin{array}{l}\text { Consejería Economía, Innovación, } \\
\text { Ciencia y Empleo, Junta de Andalucia } \\
\text { (P10- RNM-6262) }\end{array}$ & Andy Green \\
\hline & $\begin{array}{l}\text { Consejo Superior de Investigaciones } \\
\text { Cientificas }\end{array}$ & Mrs. Cristina Coccia \\
\hline Abstract: & \multicolumn{2}{|c|}{$\begin{array}{l}\text { Trichocorixa verticalis verticalis, a North American water boatman, is the only alien } \\
\text { corixid in European fresh waters. It has rapidly spread, becoming the dominant corixid } \\
\text { in and around the Doñana protected area in SW Spain. Its high abundance and similar } \\
\text { morphology to native corixids suggest that T. verticalis may impact them through } \\
\text { competition for food. Here we used stable isotopes of nitrogen }(\mathrm{N}) \text { and carbon }(\mathrm{C}) \text { and } \\
\text { Bayesian analytical tools to investigate niche partitioning between } \mathrm{T} \text {. verticalis and the } \\
\text { native water boatman Sigara lateralis and S. scripta through a combination of } \\
\text { experimental and field data. Species sampled from permanent ponds and laboratory } \\
\text { aquaria could be separated based on their isotopic values ( } \delta 15 \mathrm{~N} \text { and } \delta 13 \mathrm{C}) \text {. S. } \\
\text { lateralis consistently showed higher } \delta 15 \mathrm{~N} \text { values than T. verticalis, suggesting that the } \\
\text { invasive species may be feeding at a lower trophic position and relying more on } \\
\text { herbivory than its native competitors. This was particularly true for the T. verticalis } \\
\text { nymph stage, which showed lower } \delta 15 \mathrm{~N} \text { values compared to adults, indicating } \\
\text { ontogenetic dietary shifts. In contrast, native corixids and the invasive species showed } \\
\text { similar isotopic compositions in temporary habitats at different stages in the flooding- }\end{array}$} \\
\hline
\end{tabular}




\begin{tabular}{|l|l|}
\hline $\begin{array}{l}\text { desiccation cycle, suggesting some degree of niche overlap and a slight reduction in } \\
\text { trophic level for S. lateralis when inhabiting ephemeral systems. The combination of } \\
\text { experimental and field data can help elucidate trophic interactions during a biological } \\
\text { invasion. Stable isotopes provided insights into the trophic ecology of this invasive } \\
\text { species and into the mechanisms facilitating co-existence with native species. }\end{array}$ \\
\hline Response to Reviewers: & $\begin{array}{l}\text { Dear Dr. Ramasubramaniam, } \\
\text { Thank you very much for finding our ms AQSC-D-15-00119 provisionally suitable for } \\
\text { publication in Aquatic Sciences once we have addressed the Editor-in-Chief } \\
\text { comments. In the new version the word corrections suggested by the EIC have been } \\
\text { taken into account. Please find attached the clean version of our manuscript. The } \\
\text { answer to the EIC is detailed below: }\end{array}$ \\
& $\begin{array}{l}\text { RESPONSES TO EIC' COMMENTS } \\
\text { EIC: Minor wording revisions will be shown in pdf sent separately. }\end{array}$ \\
\hline We have now eliminated some words and replaced others as suggested (P7; L16: \\
represent by are, P18; L6 to by for, P19; L7-8: whole structure by those recorded, and \\
P22; L1: Bibliography by References). \\
Please do not hesitate to contact us if any further improvements are needed. \\
Best regards, \\
Cristina Coccia
\end{tabular}


Cristina Coccia

Seville January 2016

Wetland Ecology Department

EBD-CSIC, Av. Américo Vespucio s/n

41092, Seville, Spain

coccia@ebd.csic.es

Dear Dr. Ramasubramaniam,

Thank you very much for finding our ms AQSC-D-15-00119 provisionally suitable for publication in Aquatic Sciences once we have addressed the Editor-in-Chief comments. In the new version the word corrections suggested by the EIC have been taken into account. Please find attached the clean version of our manuscript. The answer to the EIC (in blue) is detailed below:

\section{RESPONSES TO REVIEWERS' COMMENTS}

EIC: Minor wording revisions will be shown in pdf sent separately.

We have now eliminated some words and replaced others as suggested (P7; L16: represent by are, P18; L6 to by for, P19; L7-8: whole structure by those recorded, and P22; L1: Bibliography by References).

Please do not hesitate to contact us if any further improvements are needed.

Best regards,

Cristina Coccia 
1 Niche partitioning between invasive and native corixids (Hemiptera, 2 Corixidae) in south-west Spain.

3

4 Cristina Coccia ${ }^{1 *}$, Brian Fry ${ }^{2}$, Francisco Ramírez ${ }^{3}$, Luz Boyero ${ }^{1,4,5}$, Stuart E. Bunn², Carmen 5 Diz-Salgado $^{1}$, Mark Walton ${ }^{6}$, Lewis Le Vay ${ }^{6}$ and Andy J. Green ${ }^{1}$

7 'Department of Wetland Ecology, Doñana Biological Station (EBD-CSIC), Américo 8 Vespucio s/n, 41092 Seville, Spain

$9 \quad{ }^{2}$ Australian Rivers Institute, Griffith University, Nathan, Queensland, Australia, 4111

$10{ }^{3}$ Department of Biological Conservation, Doñana Biological Station (EBD-CSIC), Américo 11 Vespucio s/n, 41092 Seville, Spain

$12{ }^{4}$ Present address: Faculty of Science and Technology, University of the Basque Country 13 (UPV/EHU), Leioa, Spain

$14{ }^{5}$ Present address: IKERBASQUE, Basque Foundation for Science, Bilbao, Spain

$15 \quad{ }^{6}$ Centre for Applied Marine Sciences, Bangor University, Wales, UK

16 *Corresponding author: coccia@ebd.csic.es

\section{Acknowledgements}

18 This research was funded by project P10- RNM-6262 financed by the Consejería de 19 Innovación, Ciencia y Empresa, Junta de Andalucía, and by a JAE predoctoral grant from 20 CSIC. Permission to work in Veta la Palma was provided by Pesquerías Isla Mayor, S.A. We 21 are grateful to Raquel López Luque for laboratory and field assistance and to Renaud de 22 Stephanis and Ricardo Alvarez for their useful advice. We are also grateful to David 23 Aragonés Borrego for preparing the map of the study area 


\section{Abstract}

2 Trichocorixa verticalis verticalis, a North American water boatman, is the only alien corixid

3 in European fresh waters. It has rapidly spread, becoming the dominant corixid in and around

4 the Doñana protected area in SW Spain. Its high abundance and similar morphology to native

5 corixids suggest that $T$. verticalis may impact them through competition for food. Here we

6 used stable isotopes of nitrogen $(\mathrm{N})$ and carbon $(\mathrm{C})$ and Bayesian analytical tools to

7 investigate niche partitioning between $T$. verticalis and the native water boatman Sigara

8 lateralis and S. scripta through a combination of experimental and field data. Species sampled

9 from permanent ponds and laboratory aquaria could be separated based on their isotopic

10 values $\left(\delta^{15} \mathrm{~N}\right.$ and $\left.\delta^{13} \mathrm{C}\right) . S$. lateralis consistently showed higher $\delta^{15} \mathrm{~N}$ values than $T$. verticalis, 11 suggesting that the invasive species may be feeding at a lower trophic position and relying 12 more on herbivory than its native competitors. This was particularly true for the T. verticalis

13 nymph stage, which showed lower $\delta^{15} \mathrm{~N}$ values compared to adults, indicating ontogenetic 14 dietary shifts. In contrast, native corixids and the invasive species showed similar isotopic 15 compositions in temporary habitats at different stages in the flooding-desiccation cycle, 16 suggesting some degree of niche overlap and a slight reduction in trophic level for $S$. Iateralis 17 when inhabiting ephemeral systems. The combination of experimental and field data can help 18 elucidate trophic interactions during a biological invasion. Stable isotopes provided insights 19 into the trophic ecology of this invasive species and into the mechanisms facilitating co20 existence with native species.

Key words: Invasive species, Corixidae, Trichocorixa, Sigara, Stable isotopes, Niche partitioning 


\section{Introduction}

Invasion by exotic species is a global ecological and conservation problem, causing community change and species extinctions worldwide (Crowl et al. 2008; Vilà et al. 2010; Hermoso, et al., 2011; Strayer 2012). The impact caused by biological invasions can range from undetectable to dramatic (Edelaar and Tella 2012) depending partly on how invasive species traits, including behaviour or physiology, match those of natives in the invaded community (Strauss et al. 2006). Several studies have related traits such as competitive ability for food and/or space to invasion success, as invasive species are often considered superior competitors (Levine et al. 2003; Vilà and Weiner, 2004).

When competition occurs, the degree of resource/niche overlap among invasive and native species largely determines species exclusion or co-existence (De Roos et al. 2008). Niche similarity between species can cause the strongest impact on inferior competitors (Dick 2008) through behavioural alterations (i.e., shifts in habitat use and foraging niche) or species exclusion and extinction (Begon et al. 1996; Simon and Townsend 2003). In contrast, niche differentiation, in which competing species specialise on distinct resources (resource partitioning) or exploit the same resources at different places or times (spatial or temporal niche partitioning), favours species co-existence (Koch 1974; Tilman 1982; Chesson 2000).

The outcome of species relationships, however, is context specific (Chesson 2000). For example, competitive interactions, within and between species, may be reversed among habitats that differ in productivity and resource diversity (Tobler 2008). In recent years, stable isotopes and novel quantitative metrics have been shown to be valuable tools in identifying trophic niche characteristics and trophic interactions among species (Olsson et al. 2009; Zambrano et al. 2010; Piscart et al. 2011; Eloranta et al. 2013; Jackson and Britton 2013). Stable isotopes are especially powerful because they integrate information over long time periods (Bearhop et al. 2004; Olsson et al. 2009; Atkinson et al. 2010), and do not have the 
1 biases of gut analysis (Clarke et al. 2005; Araújo et al. 2007) which is difficult to apply in

2 small animals, given the difficulties of identifying material in their guts.

3 Freshwater habitats have proportionally more invaders than terrestrial systems (Vitousek

4 et al. 1997). Nonetheless, for the majority of these invaders the effects on the invaded systems

5 are largely unknown. Exceptions include the zebra mussel Dreissena polymorpha, the 6 mosquitofish Gambusia holbrooki and the crayfish Procambarus clarkii (Pimentel et al. 7 2005; Caiola and Sostoa, 2005; Savini et al. 2010). The North American boatman 8 Trichocorixa verticalis verticalis (Fieber, 1851) (Heteroptera, Corixidae) is a successful 9 invader in the south-west Iberian Peninsula. First recorded in the Algarve (Portugal) in 1997, west Spain (Rodríguez-Pérez et al. 2009) and Morocco (L’Mohdi et al. 2010), and is predicted to spread widely across Europe and the Mediterranean region in the future (Guareschi et al. 2013). It has established populations at several sites, including the Doñana wetland complex, where it is the dominant corixid in saline wetlands, whilst is still scarce in less saline waters in the same area (Rodríguez-Pérez et al. 2009; Van de Meutter et al. 2010). Given the voracity of $T$. verticalis in its native range (Wurtsbaugh 1992) and the morphological similarity of piercing and sucking mouthparts within Hemiptera, we can expect resource competition between the invasive corixid and native corixids, especially Sigara lateralis and S. scripta, which are often syntopic in the invaded range (Carbonell et al. 2015). Furthermore, the wide spectrum of potential food used by T. verticalis, including zooplankton, filamentous algae and dipteran larvae (Kelts 1979; Simonis 2013) suggests that other important ecological interactions might occur. In its native range, T. verticalis is likely to cause changes in ecosystem processes via trophic cascades (Wurtsbaugh 1992; Simonis 2013). Nonetheless, there is no previous information about trophic relationships between $T$. verticalis and native corixid species, or about its trophic ecology in the invaded areas. 
In this study we applied stable isotopes $\left(\delta^{15} \mathrm{~N}\right.$ and $\left.\delta^{13} \mathrm{C}\right)$ and Bayesian tools to

2 experimental and field data to assess the potential of $T$. verticalis to compete with native

3 corixid species. We are not aware of any previous stable isotope studies of resource

4 partitioning that compare stable isotopic variability between related species that include both

5 laboratory and wild populations. This approach offers the possibility to examine the trophic

6 relationships between species, removing biases that may be related to spatial or age

7 variability. Specifically, we examine niche partitioning among wild populations of $T$.

8 verticalis and native corixids in permanent and temporary waterbodies in Doñana, as well as

9 in experimental populations reared in the laboratory under standardized conditions, so as to

10 understand how their trophic relationships change according to habitat variability. We

11 hypothesised that niche differentiation through resource partitioning facilitates the co-

12 existence in permanent, saline ponds where resource availability is expected to be more 13 constant. However, we expected a different outcome of species interactions in temporary 14 waterbodies where $T$. verticalis was often less abundant than native corixids and resource

15 availability should be more variable. In addition, we aimed to further our understanding of the 16 trophic ecology of $T$. verticalis in the introduced range, and of its potential impact in the 17 invaded aquatic systems. Finally, we discuss the implications of our results for conservation 18 of native corixids and prey communities.

\section{Methods}

\section{Laboratory experiment}

To reduce the effect of factors other than niche partitioning that may potentially confound 23 isotopic differences between corixids (e.g. age-related dietary differences or spatial 24 segregation), a laboratory experiment was conducted during August and September 2012 at 
1 the Doñana Biological Station-CSIC. Aquaria $(6 \mathrm{~L}, 27 \times 17 \times 18 \mathrm{~cm})$ were filled with sediments

2 and water collected from the FAO pond within Doñana National Park, where T. verticalis and

3 S. lateralis were co-existing. Salinity in aquaria was less than 1 ppt. One plastic circular jar

4 lid ( $\sim 9 \mathrm{~cm}$ diameter) was added to each aquarium as a substrate for periphyton growth. From

5 here on, we use periphyton to refer to epilithon (periphyton growth on hard substrate) and

6 epiphyton (periphyton on macrophyte). Aquaria were maintained with a $12 \mathrm{~h}: 12 \mathrm{~h}$ dark/light 7 regime until flora and fauna from egg and seed banks within pond sediment colonized them. 8 After three weeks, we added $\mathrm{V}$ instar corixid nymphs to each aquarium. These nymphs had

9 been reared in the laboratory from the egg stage. To collect eggs, adults of T. verticalis and $S$. lateralis originating from the FAO pond were placed separately in aquaria containing 5 X 5 $11 \mathrm{~cm}$ of $500 \mu \mathrm{m}$ plastic mesh (known from previous observations to be a preferred substrate for 12 egg laying). Mesh pieces were later carefully removed and placed in separate aquaria until 13 eggs hatched. Nymphs were then fed with lyophilized microalgae (Tetrase/mis chuii) until 14 they reached the $\mathrm{V}$ instar.

We added 15 nymphs of each species in the same aquarium, with two replicates. Live 16 chironomid larvae from the FAO pond were added one day after the experiment started. After 1712 days, adult corixids and resources were removed and processed for stable isotope analysis. 18 This time is considered to capture the overall isotope change in invertebrates when changing their diet (Prasifka et al. 2004; Gratton and Forbes 2006).

21 Field study

22 Corixids and their potential food resources were collected during June-July 2011 and 23 February 2012 from areas within the Doñana wetland complex (Fig. 1). Five permanent, 24 saline ponds, located in Veta la Palma estate within Doñana Natural Park (hereafter VLP), 25 were sampled twice during summer (July) and winter (February). Four temporary waterbodies 
1 were sampled only once (June). These sites were inside Doñana National or Natural Park and

2 included two ponds (local names 9N3PP and $\mathrm{AC} 3$, hereafter $\mathrm{T} 1$ and $\mathrm{T} 2$ ), one section of a

3 seasonal stream (Entremuros, hereafter T3), and one shallow lake (Lucio del Lobo, hereafter

4 T4). These temporary sites started to fill in December 2010, and to dry out progressively in 5 June 2011. The colonization of these ponds by adult corixids started in March 2011 with a 6 few individuals, but densities of adults and nymphs increased from then on (authors' 7 unpublished data). Sampling in June therefore decreased the probability of collecting migrants 8 from the VLP ponds. Water salinities varied spatially and temporally, from 8.7 and 19.8 psu

9 in summer to 10.2 and 18.3 psu in winter in permanent ponds, and between 5.4 and 15.9 psu

11 community are given by Rodriguez-Pérez and Green (2012) and Walton et al. (2015). The 12 temporary sites were described by Frisch et al. (2012).

13 In general, the alien $T$. verticalis is much more abundant and dominates in the permanent, 14 saline habitats in VLP, whereas native corixids dominate in the temporary sites of lower 15 salinity (Rodríguez-Pérez et al. 2009; Van de Meutter et al. 2010). We selected Sigara 16 lateralis and S. scripta because they are the most frequent and abundant corixids found in 17 syntopy with $T$. verticalis. Corixid size differed between species, with $S$. lateralis (mean total 18 length \pm SE, $4.73 \pm 0.25 \mathrm{~mm}, n=103$, ) the larger species, followed by $S$. scripta $(4.39 \pm 0.25$ $19 \mathrm{~mm}, n=93)$ and $T$. verticalis $(4.16 \pm 0.32 \mathrm{~mm}, n=111)$.

20 When possible, 20 adults of each species, balanced for sex, were collected. Nymphs (III, IV 21 and $\mathrm{V}$ instars) of $T$. verticalis were only obtained in February from permanent ponds. No 22 adult corixids were found in two of the five permanent ponds sampled in winter. Details of 23 sampling methods for flora and fauna in permanent and temporary sites are summarized in 24 Online Resource 2. With the exception of periphyton, potential resources were always 25 collected at different locations within permanent ponds, because they were also used for a 
1 broader study of pond food webs (Walton et al. 2015). In the case of temporary waterbodies,

2 corixids and resources were collected in the same area $\left(\mathrm{ca} .20 \mathrm{~m}^{2}\right)$ within the site.

3 After collection, samples were kept inside plastic containers partly filled with water,

4 placed within a portable freezer and transported to the laboratory. Once at the laboratory,

5 suspended particulate organic matter (POM) was obtained by filtering a known volume of 6 water (pre-filtered through a $100 \mu \mathrm{m}$ mesh) onto Whatman GF/F glass fiber filters ( $\varnothing=47$ $7 \mathrm{~mm}$ ) under vacuum. Filters were then packed into aluminium paper and frozen. The 8 periphyton suspension (Online Resource 2) was filtered through Whatman GF/F glass fiber

9 filters in the same way POM. Flora and fauna were rinsed with distilled water and put in 10 Eppendorf tubes $(1.5 \mathrm{ml})$ or in plastic bags before being frozen. Samples were frozen as soon 11 as possible using a liquid nitrogen tank and stored until processing. All samples were thawed 12 and oven-dried at $50^{\circ} \mathrm{C}$ for $24 \mathrm{~h}$ before stable isotope analysis.

$13 \quad$ POM and periphyton were exfoliated from the glass filters and pulverized. POM filters 14 from VLP were fumigated with concentrated $\mathrm{HCl}$ and subsequently re-dried. VLP sediments 15 were sequentially acidified with $0.1 \mathrm{M} \mathrm{HCl}$ to remove carbonates then oven-dried, while 16 sediments from the temporary sites were divided into two groups. For $\delta^{13} \mathrm{C}$ analyses, 17 subsamples were washed with diluted $\mathrm{HCl}$ to remove carbonates and redried. $\delta^{15} \mathrm{~N}$ was 18 measured on untreated samples, as $\mathrm{HCl}$ treatment has been reported to affect $\delta^{15} \mathrm{~N}$ values 19 (Bunn et al. 1995). In both study areas, sediments were considered as a proxy for periphyton 20 (i.e. epipelon).

21 Adult corixids from VLP were analyzed whole, while adults minus one leg were analysed 22 from temporary sites. T. verticalis nymphs and chironomids were pooled for analyses, as 23 samples of multiple individuals. Dry samples were homogenised, weighed and packed into tin 24 capsules before analysis. 
1 Stable isotope analysis

Isotopic analyses of carbon and nitrogen contents were carried out at the UC Davis Stable Isotope Facility (University of California, Davis) and in the Laboratory of Stable Isotopes at EBD-CSIC (www.ebd.csic.es/lie/index.html). At UC Davis, samples from VLP were analysed using a PDZ Europa Scientific Roboprep elemental analyser in line with a PDZ Europa Hydra 20/20 isotope ratio mass spectrometer (Crewe, UK). At the EBD-CSIC, samples of the laboratory experiment and temporary sites (each about $0.9-1 \mathrm{mg}$ ) were combusted using a continuous flow isotope-ratio mass spectrometry system by means of a Flash HT Plus elemental analyser coupled to a Delta- $\mathrm{V}$ Advantage isotope ratio mass spectrometer via a CONFLO IV interface (Thermo Fisher Scientific, Bremen Germany).

1 All isotope results are expressed in $\delta$-notation as parts per thousand (\%o) deviation, and referred to international standards for nitrogen (i.e., Air) and carbon (i.e., Vienna Pee Dee Belemnite $)$ as defined by the equation: $\delta^{13} \mathrm{C}, \delta^{15} \mathrm{~N}=\left[\left(\mathrm{R}_{\text {sample }} / \mathrm{R}_{\text {reference }}\right)-1\right] \mathrm{X} 10^{3}$, where $\mathrm{R}=$ ${ }^{13} \mathrm{C} /{ }^{12} \mathrm{C}$ for carbon and ${ }^{15} \mathrm{~N} /{ }^{14} \mathrm{~N}$ for nitrogen. The standard error (based on replicate analyses of standard reference material) for samples measured at UC Davis was $\pm 0.1 \%$ and $\pm 0.1 \%$ o for $\delta^{13} \mathrm{C}$ and $\delta^{15} \mathrm{~N}$, respectively and for samples measured at EBD-CSIC was $\pm 0.05 \%$ and \pm $0.1 \%$ for $\delta^{13} \mathrm{C}$ and $\delta^{15} \mathrm{~N}$, respectively. Online Resource 3 gives the standard reference materials used at each laboratory.

A total of 505 corixids (277 T. verticalis, 160 S. lateralis and 68 S. scripta) were analyzed from field studies, and 34 (18 T. verticalis and $16 \mathrm{~S}$. lateralis) from laboratory experiments. C:N ratios ranged from 3.5 to 3.9 for $S$. lateralis, T. verticalis and $S$. scripta, so $\delta^{13} \mathrm{C}$ values were not corrected according to differences in lipid contents (Post et. al. 2007). 


\section{Statistical analyses}

Non parametric Kruskal-Wallis or Mann-Whitney U tests were used to test for differences in $\delta^{13} \mathrm{C}$ and $\delta^{15} \mathrm{~N}$ values among species, or between $T$. verticalis adults and nymphs. These tests were conducted within each waterbody (permanent or temporary) or aquarium. Significance levels of non-parametric post hoc tests were Holm-Bonferroni corrected, when appropriate.

These non-parametric tests were also used to test for spatial (among ponds) differences in isotopic values for species and food sources, and seasonal differences in T. verticalis isotopic composition and food sources. These analyses were conducted using the ponds sampled in both seasons ( 3 permanent ponds) and the food sources sampled in each pond (i.e. sediments and POM).

\section{Estimated trophic position within habitats}

Within each aquarium or waterbody (permanent and temporary) we constructed the mixing polygon of potential sources and corrected consumer data for trophic enrichment using the values reported by McCutchan et al. (2003): $\Delta^{13} \mathrm{C} 0.5 \%$ and $\Delta^{15} \mathrm{~N} 2.3 \%$ for corixids with mixed diet. We also estimated the relative mean trophic position of corixids by using POM as the baseline. POM was selected as an appropriate baseline because this was the resource common to each studied system. Given the larger error associated with the use of primary producers (Vander Zanden and Rasmussen 2001), absolute values for these estimates must only be considered as a proxy of their actual trophic position. However, since corixid $\delta^{15} \mathrm{~N}$ values were corrected for site-specific $\delta^{15} \mathrm{~N}$ baselines, these estimates are still useful for evaluating differences in trophic positions across systems. 
Niche width and trophic structure

To visualise how corixid populations were separated, or overlapped each other in $\delta^{13} \mathrm{C}$ -

$3 \quad \delta^{15} \mathrm{~N}$ bi-plot space within each system, we calculated Standard Ellipse Areas corrected for 4 sample size $\left(\mathrm{SEA}_{\mathrm{c}}\right.$ expressed in $\%^{2}$ ) following Jackson et al. (2011) and using Bayesian 5 Stable Isotopes Ellipses (SIBER) in the SIAR package in R. Standard ellipses contained ca. $640 \%$ of the data, and were obtained from the variance and covariance matrix of $x\left(\delta^{13} \mathrm{C}\right)$ and $y$ $7 \quad\left(\delta^{15} \mathrm{~N}\right)$ data. Therefore, an ellipse represents the core isotopic niche for each species and is a 8 proxy of the richness and evenness of resources consumed by the population (Bearhop et al. 9 2004). When the spatial variation in corixid isotopic composition could be dismissed 10 (Cummings et al. 2012), the SEAc was used to calculate the degree of standard ellipse overlap 11 between species within each individual pond (i.e. the percentage of area that overlaps relative 12 to the total isotopic niche occupied by the two species), and the Bayesian estimates of SEA 13 (SEA ${ }_{\mathrm{B}}$, bootstrapped $\left.n=10000\right)$ were generated to test for significant differences between 14 corixid isotopic niche widths by comparing their confidence intervals (Jackson et al. 2012). 15 The SEAc method is equivalent to the convex hull area proposed by Layman et al. (2007), 16 and has the advantage of avoiding any bias (Brind'Amour and Dubois 2013) when a 17 minimum of 20 individuals is used, as we often did in this study. However, slightly lower 18 sample sizes are also less biased if the variability in populations is low (Syväranta et al. 19 2013). Jackson et al. (2011) further discussed the relationship between SEA, SEAc and SEA 20 We tested for the distance between ellipse centroid locations (D) following the methodology 21 of Turner et al. (2010). Two centroids are considered to occupy different locations if the 22 distance between them is significantly greater than zero (Turner et al. 2010). All these metrics 23 and test statistics were performed with R (v 2.15.1), using the package SIAR (Jackson et al. 24 2011) and the scripts provided by Turner et al. (2010). 
1 Results

2

\section{Stable Isotopes}

T. verticalis had significantly lower $\delta^{15} \mathrm{~N}$ values than $S$. Iateralis in each aquarium (MannWhitney $\mathrm{U}$ tests $\mathrm{P}<0.05$, Fig. 2), but $\delta^{13} \mathrm{C}$ values differed significantly only in the second aquarium AQ2 (mean isotopic differences between species: $0.3 \%$ for $\delta^{13} \mathrm{C}$ and $3.6 \%$ for $\delta^{15} \mathrm{~N}$ at $\mathrm{AQ} 1 ; 1.1 \%$ for $\delta^{13} \mathrm{C}$ and $1.7 \%$ for $\delta^{15} \mathrm{~N}$ at AQ2, Table 1$)$.

T. verticalis and $S$. lateralis showed significant differences in both $\delta^{13} \mathrm{C}$ and $\delta^{15} \mathrm{~N}$ values within each permanent pond where they co-existed $(\mathrm{P}<0.001$, Fig. 3). On average, $S$. lateralis was more ${ }^{13} \mathrm{C}$-depleted and ${ }^{15} \mathrm{~N}$-enriched than T. verticalis (mean isotopic differences between species: $4.5 \%$ for $\delta^{13} \mathrm{C}$ and $1.3 \%$ for $\delta^{15} \mathrm{~N}$ at pond $\mathrm{A} 3 ; 2.5 \%$ for $\delta^{13} \mathrm{C}$ and $3.3 \%$ for $\delta^{15} \mathrm{~N}$ at pond $\mathrm{B} 3$, Table 1). We did not find isotopic differences among the ponds where both species co-existed for T. verticalis $(\mathrm{P}>0.05)$, but a significant difference in $\delta^{13} \mathrm{C}(\mathrm{P}=0.02)$ was found for $S$. lateralis. We did not find any significant differences in the isotope values of the common trophic sources between ponds $(\mathrm{P}>0.05)$.

T. verticalis adults were more ${ }^{15} \mathrm{~N}$-enriched than nymphs at permanent ponds B7 (0.9\%) and A5 $(1.0 \%)(\mathrm{P}<0.05)$, and significantly more ${ }^{13} \mathrm{C}$-depleted $(2.4 \%)$ than nymphs at pond B7 $(\mathrm{P}=0.006)$. No differences were found between adults and nymphs at pond A7 (Online Resource 4). Adults of $T$. verticalis showed significant spatial differences in both $\delta^{13} \mathrm{C}$ and $\delta^{15} \mathrm{~N}$, but we did not find any isotopic differences for sediments or POM $(\mathrm{P}>0.05)$ between ponds.

Strong seasonal differences were also found for $\delta^{13} \mathrm{C}$ and $\delta^{15} \mathrm{~N}$ values $(\mathrm{P}<0.05)$. In winter, T. verticalis was overall more ${ }^{13} \mathrm{C}$-depleted (mean $=-18.4 \%$ ) but ${ }^{15} \mathrm{~N}$-enriched (mean $=11.4 \%$ ) than in summer (mean $\delta^{13} \mathrm{C}=-16.7 \%$; mean $\delta^{15} \mathrm{~N}=9.7 \%$ ). We did not find any seasonal differences in $\delta^{13} \mathrm{C}$ for sediments or POM $(\mathrm{P}>0.05)$, but there was a significant 
1 seasonal difference in $\delta^{15} \mathrm{~N}$ value in each food source $(\mathrm{P}<0.05)$. In winter, values for

2 sediments and POM were more ${ }^{15} \mathrm{~N}$-depleted than in summer (sediments mean $=8.06$ vs.

3 11.20; POM mean = 2.52 vs. 6.16) $($ Online Resource 5).

Interspecific differences in isotopic values were more pronounced among temporary sites (Fig. 4). T. verticalis was significantly ${ }^{13} \mathrm{C}$-enriched at waterbody $\mathrm{T} 1$ relative to $S$. lateralis and S. scripta, but the opposite was observed at T2 (Holm-Bonferroni test $\mathrm{P}<0.05$ ). The alien species was significantly enriched in ${ }^{13} \mathrm{C}$ relative to $S$. Iateralis at $\mathrm{T} 4(\mathrm{P}<0.001)$, but depleted in ${ }^{13} \mathrm{C}$ compared to $S$. scripta at $\mathrm{T} 3(\mathrm{P}=0.01$, Table 1$)$. T. verticalis was significantly depleted in ${ }^{15} \mathrm{~N}$ compared to both native species at $\mathrm{T} 1(\mathrm{P}<0.001$, Table 1$)$ and to S.lateralis at $\mathrm{T} 4(\mathrm{P}=$ 0.03). Strong spatial differences between temporary sites were also found for T. verticalis and S. scripta in $\delta^{13} \mathrm{C}$ values (Kruskal-Wallis test $\mathrm{P}<0.001$ ) and in both $\delta^{13} \mathrm{C}$ and $\delta^{15} \mathrm{~N}$ values for S. lateralis $(\mathrm{P}<0.001)$. Both $\delta^{13} \mathrm{C}$ and $\delta^{15} \mathrm{~N}$ values of sediments and $\mathrm{POM}$ also differed among sites $(\mathrm{P}<0.05)$. Spatial differences were found in $\delta^{15} \mathrm{~N}$ for periphyton $(\mathrm{P}=0.03)$ and in $\delta^{13} \mathrm{C}$ for chironomids $(\mathrm{P}=0.01)$, but we did not find any isotopic difference for Scirpus spp. among sites $(\mathrm{P}>0.05)$ (Online Resource 6).

\section{Estimated trophic position within habitats}

The estimated mean ( \pm SD) trophic position was at $3.3 \pm 1.4$ for $S$. lateralis and at $2.1 \pm$ 1.2 for T. verticalis in the laboratory experiment (Fig. 2). Similarly, in permanent ponds S.lateralis fed at a higher trophic level $(3.4 \pm 0.4)$ than $T$. verticalis $(2.4 \pm 0.1)$. In temporary waterbodies, the mean estimated trophic position was at $2.1 \pm 0.9$ for S./ateralis, at $1.9 \pm 0.7$ for S. scripta and at $1.7 \pm 0.8$ for T. verticalis.

\section{Niche width differences among species}

$\mathrm{SEA}_{\mathrm{B}}$ values did not differ significantly between $T$. verticalis and S. lateralis within each 
1 aquarium where they co-existed, and $\mathrm{SEA}_{\mathrm{c}}$ showed complete segregation (Table 2).

$2 \mathrm{SEA}_{\mathrm{B}}$ comparisons between $T$. verticalis and $S$. lateralis were not performed within each

3 permanent pond or between them, as the observed subsets within species (Fig. 3) could be

4 largely the result of spatial variability in the isotopic composition either between or among 5 ponds, preventing a reliable comparison of their dietary and isotopic niche variability.

6 Nevertheless, it was evident that no $\mathrm{SEA}_{\mathrm{c}}$ overlap existed between species at A3 and B3.

\section{Discussion}

To our knowledge, this is the first isotopic study that compares trophic relationships between invasive and native aquatic insects in different ecosystems, supported by an experimental approach. Stable isotopes revealed strong resource partitioning between species with little or no isotopic niche overlap in permanent ponds when water levels are relatively stable, but also some degree of niche overlap in unstable temporary sites. These results are in agreement with niche theory predictions, as native and invasive corixids appear to partition the resources to co-exist in response to restrictions in resource conditions. This resource partitioning has the potential to affect the distribution and abundance of the native species, 
1 resulting from inadequate nutrient intake due to resource limitations or from the energetic

2 investments required for catching prey.

3

\section{$4 \quad$ Limitations of this study}

During this study we encountered some of the limitations observed in other isotopic studies, including a high degree of spatial and temporal variability in basal resources. We cannot be sure to what extent the isotope variability among ponds derived from movement and foraging of individuals in different sites, diet specialization or differences in the magnitude of variation of basal resources between sites (Bolnick et al. 2003; Bearhop et al. 2004). In addition, various physiological processes, including life stage, growth rate or body size (Fry and Arnold 1982; Haubert et al. 2005; Carleton and Martínez del Rio 2005) may have also influenced the istopic variability of corixids found in this study.

Lastly, for resources composed of a mixture of components, such as POM and periphyton the variability may have been a product of other factors including seasonal changes in species composition and growth rate, slight differences at a microscale level and differences in the proportion of living organisms and detritus between samples (Trudeau and Rasmussen 2003; Borduqui, Ferragut and Bicudo 2008; Gu 2009).

We are unable to assess the relative contribution of these factors to the observed variability in species isotopic composition between sites, but this was not our objective. Our results support the initial predictions of changes in the relative position of $\delta^{13} \mathrm{C}$ and $\delta^{15} \mathrm{~N}$ values between co-existing invasive and native corixids among the studied habitats. This provided new information about the mechanisms behind the co-existence of $T$. verticalis and native corixids in Doñana, and furthers our understanding of the basis of the success of $T$. verticalis in the introduced range. 


\section{$2 \quad$ Permanent ponds and aquaria}

3 A prerequisite for species co-existence in stable habitats, assuming that consumers and

4 resources are all in equilibrium, is that species must exploit different resources to survive 5 (Hutchinson 1958). We found consistent differences in both $\delta^{13} \mathrm{C}$ and $\delta^{15} \mathrm{~N}$ values between the

6 native and the invasive species in both permanent ponds and experimental aquaria, and no

7 isotopic niche overlap between them. We cannot exclude the possibility that $S$. Iateralis found

8 in saline permanent ponds were migrants that had been feeding in other sites of low salinity

9 with different food resources (Velasco et al. 2006). However, our aquarium experiment

10 indicated that when confined in the same conditions, T. verticalis and S. lateralis fed on

11 different food items, facilitating their co-existence.

Omnivorous corixids such as T. verticalis and S. lateralis (Murillo and Recasens 1986; Simonis 2013) possess similar piercing-sucking mouthparts (stylets) suitable for feeding on both plants and animals. However, previous studies have confirmed the importance of animal prey to $S$. lateralis (Murillo and Recasens 1986; Layer et al. 2010) and others have found $T$. verticalis to be predators on Cladocera and Artemia in its native range (Wurtsbaugh 1992; Simonis 2013). In contrast, our results showed that T. verticalis fed at a lower trophic level than $S$. lateralis both in the experimental aquaria and in permanent ponds, and suggest a tendency of $T$. verticalis towards herbivory and a higher importance of animal prey for $S$. lateralis. This may partly be explained by the salinity of the permanent ponds we studied, which are too saline for cladocerans but are not hypersaline and have no Artemia (Frisch et al. 2006). Our data did not allow a detailed assessment of corixid diets, as many corixids fell outside the polygons that could be constructed with measured resources within each system, so we are not able to estimate if small or large differences exist in their diet. However, plants and animals from the laboratory experiment had sufficiently distinct $\delta^{13} \mathrm{C}$ values to aid 
1 approximate identification of their diet. In fact, the close isotopic value of Chironomidae and

2 Oligochaeta to $S$. lateralis (Fig. 2) suggested their inclusion in its diet. In contrast, $T$.

3 verticalis did not appear to be heavily reliant on animal prey (Fig. 2).

4 There was evidence of larger inter-individual variation in the field than in the laboratory

5 experiment for both species. Wide isotopic variation in wild populations is common in nature,

6 due to sexual or age differences, diet specialization and spatial variation (Fry et al. 1999;

7 Layman and Allgeier 2012). While we were unable to pinpoint the exact mechanism behind

8 this variation, it seems possible that spatial heterogeneity in basal resource values, within or

9 among ponds, explains the clustering of isotopic values we observed in each corixid species

10 in permanent ponds, and the much greater isotopic variation observed there for $T$. verticalis 11 and $S$. lateralis than in experimental aquaria.

12 Isotopic composition of sources can vary at very small scales $(<1 \mathrm{~m})$ within a freshwater 13 system (Hill et al. 2008). Similarly, our results revealed considerable isotopic variation for 14 sources within a single permanent pond (Fig. 3), and how patchiness represented by between 15 aquarium variability (Fig. 2) can affect the isotopic composition of consumers in aquaria. 16 Therefore, it is possible that, despite the ability of both species to fly between waterbodies, 17 corixids in permanent ponds are very local in their feeding strategy and faithful to a patch, 18 their isotopic values reflecting the patch availability of the resources. However, individuals 19 may also disperse and feed between ponds that differed in basal resource values. Our result 20 did not support this hypothesis, as we did not find spatial differences (among permanent 21 ponds) in the isotopic values of sources. These two possibilities need to be investigated in the 22 future by more detailed spatial analyses of consumers and sources, as such high patch fidelity 23 would represent a very surprising result for a non-sessile organism. 


\section{$\underline{\text { Temporary waterbodies }}$}

2 The isotopic values of different corixid species were very similar at some of the four 3 temporary waterbodies but very different at others. Similar isotopic values do not necessarily

4 indicate similar diet, as corixids can feed on different sources that are not distinct enough 5 isotopically to allow discrimination. Similarly, isotope niche widths were site specific for 6 each species (Fig. 4). There are several possible explanations for the observed variability in 7 species isotopic composition (see above), but our results show that some degree of niche 8 overlap might also occur between the invasive and native corixids in highly variable systems 9 (Fig. 4).

10 During summer, with high temperatures and no rainfall, temporary aquatic habitats in Doñana 11 quickly reduce their depth and surface area and dry out completely before August (Serrano et 12 al. 2006; Frisch et al. 2012). In these conditions, corixid densities become very high and 13 opportunities for $S$. lateralis to feed on preferred prey may decrease, as other invertebrates 14 become scarce. At the same time, a high quantity of detritus caused by the decomposition of 15 organic matter becomes progressively mixed and concentrated in shallow waters where 16 corixids concentrate. In these conditions of disturbance and superabundant food of low 17 diversity, some individuals of both species are likely to exploit similar resources.

18 Niche overlap is not sufficient to indicate that competition between species occurs in these 19 habitats, especially without data that directly quantifies limitation or superabundance of food. 20 However, the existence of niche partitioning and the use of similar resources among native 21 and invasive corixids indicate that competitive interactions can exist between them. 22 Furthermore, $S$. lateralis seemed to occupy a slightly lower position in temporary waters with 23 respect to aquaria. Therefore, it seems possible that higher dietary plasticity of the native 24 species is the mechanism behind its co-existence with T. verticalis. 
1 Trophic ecology of $T$. verticalis in stable permanent ponds

2 Stable isotopes suggest that the invasive species tends to be herbivorous in stable waters.

3 This result agrees with previous studies and personal observations that indicate $T$. verticalis

4 has a herbivorous strategy at the first instar stage (Campbell 1979; Kelts 1979), and a diet

5 based on periphyton as adults (Downing 2005; authors' personal observation). Periphyton is a

6 mixture of algae, cyanobacteria, heterotrophic microbes, detritus and mucilaginous

7 polysaccharides, and each of these is likely to have very different isotopic values to those

8 recorded during this study. It is possible that $T$. verticalis assimilated only some components

9 from this mixture. A periphyton-based diet is also supported by close relationships between

$10 \delta^{13} \mathrm{C}$ values of $T$. verticalis from permanent ponds with those of periphyton during winter

11 (Online Resource 5).

12 Contrary to the typical winter ${ }^{15} \mathrm{~N}$-depletion (Harrod and Grey 2006), which was found for 13 POM and sediments during this study, T. verticalis was ${ }^{15} \mathrm{~N}$-enriched. This suggests this 14 seasonal variation in $T$. verticalis $\delta^{15} \mathrm{~N}$ values was not related to change in the importance of 15 periphyton in its diet, but was most likely explained by seasonal changes within periphyton 16 composition and its $\delta^{13} \mathrm{C}$ and $\delta^{15} \mathrm{~N}$ values (Borduqui, Ferragut and Bicudo 2008) (Online 17 Resource 5). Thus, T. verticalis could be assigned to the grazer guild in our permanent pond 18 system.

19 Varying use of periphyton between permanent ponds and aquaria may partly reflect 20 differences in its composition with their different water chemistry (e.g. salinity, see Online 21 Resource 1), light intensity or with the substratum where growth occurs (i.e. rocks / solid 22 material, macrophytes and sediments). At higher nutrient concentrations, such as those of the 23 permanent ponds, periphyton may contain a higher proportion of green algae, more palatable 24 to grazers (Rejmánková and Komárková 2005). 
Different isotopic values for nymph and adult $T$. verticalis suggest an ontogenetic dietary

2 shift, as found by Simonis (2013). However, different dynamics of tissue turnover between

3 life stages (Haubert et al. 2005) or increases in consumption rate during ontogeny (Simonis

4 2013) could also contribute to isotopic shifts between nymphs and adults, at least during

5 winter. Further studies (e.g. metabarcoding of gut contents) are needed to clarify this point, as

6 ontogenetic diet shift can play an important role in explaining the success of some organisms

7 in the invaded ecosystem, by allowing a better use of resources and/or reducing competition

8 (Céréghino 2006).

\section{Conclusion}

10 We showed how trophic interactions between native and invasive corixids change between 11 permanent and temporary waterbodies. These changes seem to indicate that the extent of 12 competition among corixids changes between habitats that differed in the types and 13 abundance of local food sources. Although these are results from only one sampling 14 campaign, our findings help to elucidate the processes underlying the co-existence of these 15 species, and raise further questions about this invasion that should be addressed in the future. 16 Climate change can decrease aquatic system productivity (O'Reilly et al. 2003), which 17 implies that competition for food between native and invasive species may become exacerbated in the future. There is a need for further studies to fully understand the habitat 19 and foraging ecology of T. verticalis in its introduced range, especially since the species is expected to spread across a large part of Europe (Guareschi et al. 2013). Long-term field and mesocosm studies are required to assess the impact of this invasive species on the native corixid community (including species not covered in the present study, see Carbonell et al. in press), as well as on prey assemblages (e.g. through trophic cascades via predation on zooplankton, Simonis 2013). The effect of the invader in other habitat types where it is 
1 present in the Iberian Peninsula, such as solar saltworks (Van de Meutter et al. 2010; authors, 1 22 unpublished) should also be addressed. 


\section{References}

Araújo MS, Bolnick DI, Machado G, et al (2007) Using $\delta^{13} \mathrm{C}$ stable isotopes to quantify individuallevel diet variation. Oecologia 152:643-54.

Atkinson CL, Opsahl SP, Covich AP, et al (2010) Stable isotopic signatures, tissue stoichiometry, and nutrient cycling $(\mathrm{C}$ and $\mathrm{N})$ of native and invasive freshwater bivalves. J North Am Benthol Soc 29:496-505.

Bearhop S, Adams CE, Waldron S, et al (2004) Determining trophic niche width: a novel approach using stable isotope analysis. J Anim Ecol 73:1007-1012.

Begon M, Harper JL, Towsend CR (1996) Ecology: individual, population and communities. Blackwell Scientific Publications, London, U.K.

Bolnick DI, Svanbäck R, Fordyce JA, et al (2003) The ecology of individuals: incidence and implications of individual specialization. Am Nat 161:1-28.

Borduqui M, Ferragut C, Bicudo C (2008) Chemical composition and taxonomic structure vertical and seasonal variation of periphyton community in a shallow hypereutrophic reservoir (Garças Reservoir, São Paulo, Brazil ). Acta Limnol Bras 20:381-392.

Brind'Amour A, Dubois SF (2013) Isotopic diversity indices: how sensitive to food web structure? PLoS One 8:e84198.

Bunn SE, Loneragan NR, Kempster MA (1995) Effects of acid washing on stable isotope ratios of C and $\mathrm{N}$ in penaeid shrimp and seagrass: Implications for food-web studies using multiple stable isotopes. Limnol Oceanogr 40:622-625.

Caiola BN, Sostoa AD (2005) Possible reasons for the decline of two native toothcarps in the Iberian Peninsula: evidence of competition with the introduced Eastern mosquitofish. J Appl Ichthyol 21:358-363.

Campbell BC (1979) The spatial and seasonal abundance of Trichocorixa verticalis (Hemiptera:Corixidae) in salt marsh intertidal pools. Can Entomol 111:1005-1011.

Carbonell JA, Millán A, Green AJ, Céspedes V, Coccia C, Velasco J (2015). What traits underpin the successful establishment and spread of the invasive water bug Trichocorixa verticalis (Fieber, 1851)? Hydrobiologia. doi: 10.1007/s10750-015-2556-y.

Carleton SA, Martínez del Rio C (2005) The effect of cold-induced increased metabolic rate on the rate of ${ }^{13} \mathrm{C}$ and ${ }^{15} \mathrm{~N}$ incorporation in house sparrows (Passer domesticus). Oecologia 144:226-32.

Céréghino R (2006) Ontogenetic diet shifts and their incidence on ecological processes: a case study using two morphologically similar stoneflies (Plecoptera). Acta Oecologica 30:33-38.

Chesson P (2000) Mechanisms of maintenance of species diversity. Annu Rev Ecol Syst 31:343-366.

Clarke LR, Vidergar DT, Bennett DH (2005) Stable isotopes and gut content show diet overlap among native and introduced piscivores in a large oligotrophic lake. Ecol Freshw Fish 14:267-277.

Crowl TA, Crist TO, Parmenter RR, et al (2008) The spread of invasive species and infectious disease as drivers of ecosystem change. Front Ecol Environ 6:238-246.

Cummings DO, Buhl J, Lee RW, et al (2012) Estimating niche width using stable isotopes in the face of habitat variability: a modelling case study in the marine environment. PLoS One 7:e40539.

De Roos AM, Schellekens T, Van Kooten T, Persson L (2008) Stage-specific predator species help each other to persist while competing for a single prey. Proc Natl Acad Sci USA 105:13930-5.

Dick JTA (2008) Role of behaviour in biological invasions and species distributions; lessons from interactions between the invasive Gammarus pulex and the native G. duebeni(Crustacea: Amphipoda). Contrib to Zool 77:91-98.

Downing AL (2005) Relative effects of species composition and richness on ecosystem properties in ponds. Ecology 86:701-715.

Edelaar P, Tella JL (2012) Managing non-native species: don't wait until their impacts are proven. Ibis (Lond 1859) 154:635-637.

Eloranta AP, Knudsen R, Amundsen PA (2013) Niche segregation of coexisting Arctic charr (Salvelinus alpinus) and brown trout (Salmo trutta) constrains food web coupling in subarctic lakes. Freshw Biol 58:207-221. 
Frisch D, Cottenie K, Badosa A, Green AJ (2012) Strong spatial influence on colonization rates in a

pioneer zooplankton metacommunity. PLoS One 7:e40205.

Frisch D, Rodríguez-Pérez H, Green AJ (2006) Invasion of artificial ponds in Doñana Natural Park, southwest Spain, by an exotic estuarine copepod. Aquat Conserv Mar Freshw Ecosyst 16:483492.

Fry B, Arnold C (1982) Rapid 13C / 12C turnover during growth of brown shrimp (Panaeus aztecus). Oecologia 54:200-204.

Fry B, Mumford PL, Tam F, et al (1999) Trophic position and individual feeding histories of fish from lake Okeechobee, Florida. Can J Fish Aquat Sci 56:590-600.

Gratton C, Forbes AE (2006) Changes in $\delta^{13} \mathrm{C}$ stable isotopes in multiple tissues of insect predators fed isotopically distinct prey. Oecologia 147:615-24.

Guareschi S, Coccia C, Sánchez-Fernández D, et al (2013) How Far Could the alien boatman Trichocorixa verticalis verticalis spread? Worldwide estimation of its current and future potential distribution. PLoS One 8:e59757.

$\mathrm{Gu} \mathrm{G}$ (2009) Variation and controls of nitrogen stable isotopes in particulate organic matter of lakes. Oecologia 160: 421-431.

Harrod C, Grey J (2006) Isotopic variation complicates analysis of trophic relations within the fish community of Plußsee: a small, deep, stratifying lake. Arch für Hydrobiol 167:281-299.

Haubert D, Langel R, Scheu S, Ruess L (2005) Effects of food quality, starvation and life stage on stable isotope fractionation in Collembola. Pedobiologia (Jena) 49:229-237.

Hermoso V, Clavero M, Blanco-Garrido F, Prenda J (2011) Invasive species and habitat degradation in Iberian streams: an analysis of their role in freshwater fish diversity loss. Ecol Appl 21:17588.

Hill WR, Fanta SE, Roberts BJ $(2008){ }^{13} \mathrm{C}$ dynamics in benthic algae: Effects of light, phosphorus, and biomass development. Limnol Oceanogr 53:1217-1226.

Hutchinson GE (1958) Concluding remarks. Cold springs harbor symposium. Quant Biol 22:415-427.

Jackson AL, Inger R, Parnell AC, Bearhop S (2011) Comparing isotopic niche widths among and within communities: SIBER - Stable Isotope Bayesian Ellipses in R. J Anim Ecol 80:595-602.

Jackson MC, Britton JR (2013) Variation in the trophic overlap of invasive Pseudorasbora parva and sympatric cyprinid fishes. Ecol Freshw Fish 22:654-657.

Jackson MC, Donohue I, Jackson AL, et al (2012) Population-level metrics of trophic structure based on stable isotopes and their application to invasion ecology. PLoS One 7:e31757.

Kelts LJ (1979) Ecology of a tidal marsh corixid, Trichocorixa verticalis (Insecta, Hemiptera). Hydrobiologia 64:37-57.

Koch AL (1974) Competitive coexistence of two predators utilizing the same prey under constant environmental conditions. J Theor Biol 44:387-95.

L'Mohdi O, Bennas N, Himmi O, et al (2010) Trichocorixa verticalis verticalis (Fieber,1851) (Hemiptera,Corixidae): une nouvelle especies exotique au Maroc. Bol la Soc Entomológica Aragon 46:395-400.

Layer K, Hildrew A, Monteith D, Woodward G (2010) Long-term variation in the littoral food web of an acidified mountain lake. Glob Chang Biol 16:3133-3143.

Layman C, Allgeier J (2012) Characterizing trophic ecology of generalist consumers: a case study of the invasive lionfish in The Bahamas. Mar Ecol Prog Ser 448:131-141.

Layman CA, Arrington AD, Montana CG, Post DM (2007) Can stable isotope ratios provide for community-wide measures of trophic structure? Ecology 88:42-48.

Levine JM, Vilà M, D'Antonio CM, et al (2003) Mechanisms underlying the impacts of exotic plant invasions. Proc Biol Sci 270:775-81.

McCutchan JHJ, Lewis WMJ, Kendall C, Mcgrath CC (2003) Variation in trophic shift for stable isotope ratios of carbon, nitrogen, and sulfur. Oikos 102:378-390.

Murillo J, Recasens L (1986) Habitos alimentarios de Sigara lateralis (Heteroptera, Corixidae). Misc Zool 10:135-140.

Olsson K, Stenroth P, Nyström P, Granéli W (2009) Invasions and niche width: does niche width of an introduced crayfish differ from a native crayfish? Freshw Biol 54:1731-1740.

O'Reilly CM, Alin, SR, Plisnier, PD, Cohen, AS, McKee BA (2003) Climate change decreases aquatic ecosystem productivity of lake Tanganyika, Africa. Nature 424:766-768. 
Pimentel D, Zuniga R, Morrison D (2005) Update on the environmental and economic costs associated with alien-invasive species in the United States. Ecol Econ 52:273-288.

Piscart C, Roussel JM, Dick JTA, et al (2011) Effects of coexistence on habitat use and trophic ecology of interacting native and invasive amphipods. Freshw Biol 56:325-334.

Post DM, Layman CA, Arrington DA, Takimoto G, Quattrochi J, Montaña CG (2007) Getting to the fat of the matter: models, methods and assumptions for dealing with lipids in stable isotope analyses. Oecologia 152:159-179.

Prasifka JR, Heinz KM, Winemiller KO ( 2004) Crop colonisation, feeding, and reproduction by the predatory beetle, Hippodamia convergens, as indicated by stable carbon isotope analysis. Ecol Entomol 29:226-233.

Rejmánková E, Komárková J (2005) Response of cyanobacterial mats to nutrient and salinity changes. Aquat Bot 83:87-107.

Rodríguez-Pérez H, Florencio, Gómez-Rodríguez C, et al (2009) Monitoring the invasion of the aquatic bug Trichocorixa verticalis verticalis (Hemiptera: Corixidae) in the wetlands of Doñana National Park (SW Spain). Hydrobiologia 634:209-217.

Rodriguez-Pérez H, Green AJ (2012) Strong seasonal effects of waterbirds on benthic communities in shallow lakes. Freshw Sci 31:1273-1288.

Sala J, Boix D (2005) Presence of the nearctic water boatman Trichocorixa verticalis verticalis (Fieber, 1851) (Heteroptera, Corixidae) in the Algarve region (S Portugal). Graellsia 61:31-36.

Savini D, Occhipinti-Ambrogi A, Marchini A, et al (2010) The top 27 animal alien species introduced into Europe for aquaculture and related activities. J Appl Ichthyol 26:1-7.

Serrano L, Reina M, Martín G, et al (2006) The aquatic systems of Doñana (SW Spain): watersheds and frontiers. Limnética 25:11-32.

Simon KS, Townsend CR (2003) Impacts of freshwater invaders at different levels of ecological organisation, with emphasis on salmonids and ecosystem consequences. Freshw Biol 48:982994.

Simonis JL (2013) Predator ontogeny determines trophic cascade strength in freshwater rock pools. Ecosphere 4:1-25.

Strauss SY, Webb CO, Salamin N (2006) Exotic taxa less related to native species are more invasive. Proc Natl Acad Sci USA 103:5841-5.

Strayer DL (2012) Eight questions about invasions and ecosystem functioning. Ecol Lett 15:1199_ 210.

Syväranta J, Lensu A, Marjomäki TJ, et al (2013) An empirical evaluation of the utility of convex hull and standard ellipse areas for assessing population niche widths from stable isotope data. PLoS One 8:e56094.

Tilman D (1982) Resource competition and community structure. In: Princeton University Press NJ (ed)

Tobler M (2008) Divergence in trophic ecology characterizes colonization of extreme habitats. Biol J Linn Soc 95:517-528.

Trudeau V, Rasmussen JB (2003) The effect of water velocity on stable carbon and nitrogen isotope signatures of periphyton. Limnol. Oceanogr. 48:2194: 2199.

Turner TF, Collyer ML, Krabbenhoft TJ (2010) A general hypothesis-testing framework for stable isotope ratios in ecological studies. Ecology 91:2227-33.

Van De Meutter F, Trekels H, Green AJ, Stoks R (2010) Is salinity tolerance the key to success for the invasive water bug Trichocorixa verticalis? Hydrobiologia 649:231-238.

Vander Zanden JM, Rasmussen JB (2001) Variation in $\delta^{15} \mathrm{~N}$ and $\delta^{13} \mathrm{C}$ trophic fractionation: Implications for aquatic food web studies. Limnol Oceanogr 46:2061-2066.

Velasco J, Millán A, Hernández J, Gutiérrez C, Abellán P, Sánchez D, Ruiz M (2006). Response of biotic communities to salinity changes in a Mediterranean hypersaline stream. Saline Systems 2: $1-15$.

Vilà M, Basnou C, Pyšek P, et al (2010) How well do we understand the impacts of alien species on ecosystem services? A pan-European, cross-taxa assessment. Front Ecol Environ 8:135-144.

Vilà M, Weiner J (2004) Are invasive plant species better competitors than native plant species? evidence from pair-wise experiments. Oikos 105:229-238. 
Vitousek PM, D'Antonio CM, Loope L, et al (1997) Introduced species: a significant component of human-caused global environmental change. N Z J Ecol 21:1-16.

Walton MEM, Vilas C, Coccia C, Green AJ, Cañavate JP, Prieto A, van Bergeijk SA, Medialdea JM, Kennedy H, King J, Le Vay L (2015). The effect of water management on extensive aquaculture food webs in the reconstructed wetlands of the Doñana Natural Park, Southern Spain. Aquaculture 448: 451-463.

Wurtsbaugh WA (1992) Food-web modification by an invertebrate predator in the Great Salt Lake (USA). Oecologia 89:168-175.

Zambrano L, Valiente E, Jake Vander Zanden M (2010) Stable isotope variation of a highly heterogeneous shallow freshwater system. Hydrobiologia 646:327-336. 
Fig. 1 Map of the sampling sites in Doñana. The dark grey area in the upper figure indicates Doñana National Park and the light grey area indicates Doñana Natural Park. Five permanent ponds are labelled in Veta la Palma estate, and four temporary sites are labelled in and around the Caracoles estate.

Fig. 2 Dual-isotope food web diagram of two aquaria (AQ1 and AQ2) including Standard ellipses (solid line $=T$. verticalis; dot-dashed line $=S$. lateralis) showing differences in $T$. verticalis and $S$. lateralis isotope values. Food web components: $\mathrm{CHI}=$ chironomidae; PER = periphyton; POM = particulate organic matter; OLI = oligochaeta; $\mathrm{MAC}=$ macrophytes; SED $=$ sediments; $\mathrm{ZOO}=$ zooplankton. Dotted lines represent the mixing polygons circumscribed by the isotopic signature of several resources (mean $\delta^{13} \mathrm{C}$ and $\delta^{15}$ ). Corixid $\delta^{13} \mathrm{C}$ and $\delta^{15} \mathrm{~N}$ values were corrected for trophic enrichment.

Fig. 3 Dual-isotope food web diagram of two permanent ponds (A3 and B3) showing the Standard ellipse area (SEAc) of T. verticalis (solid line) and $S$. lateralis (dot-dashed line). $\mathrm{CHI}=$ chironomidae; $\mathrm{COP}=$ copepods; $\mathrm{DAP}=$ Daphnia sp.; $\mathrm{POM}=$ particulate organic matter, SED = sediments; $\mathrm{C} 3=$ Phragmites sp.; $\mathrm{C} 4=$ Ruppia sp.; Spartina sp; and Potamogeton pectinatus. Dotted lines represent the mixing polygons circumscribed by the isotopic signature of several resources (mean $\delta^{13} \mathrm{C}$ and $\delta^{15} \pm \mathrm{SD}$ ). Corixid $\delta^{13} \mathrm{C}$ and $\delta^{15} \mathrm{~N}$ values were corrected for trophic enrichment.

Fig. 4 Dual-isotope food web diagram of 4 temporary waterbodies (T1-T4) showing the Standard ellipse area (SEAc) of T.verticalis (solid line), S. lateralis (dot-dashed line) and $S$. scripta (dotted line). $\mathrm{ALG}=$ filamentous algae; $\mathrm{CHI}=$ chironomidae; $\mathrm{POM}=$ particulate organic matter; SCI = Scirpus sp.; PER = periphyton; SED = sediments; RUP = Ruppia sp.; SCR $=$ Scirpus sp. + Ruppia sp. Dotted lines represent the mixing polygon circumscribed by the isotopic signature of several resources (mean $\delta^{13} \mathrm{C}$ and $\delta^{15} \mathrm{~N} \pm \mathrm{SD}$ ). Corixid $\delta^{13} \mathrm{C}$ and $\delta^{15} \mathrm{~N}$ values were corrected for trophic enrichment. 


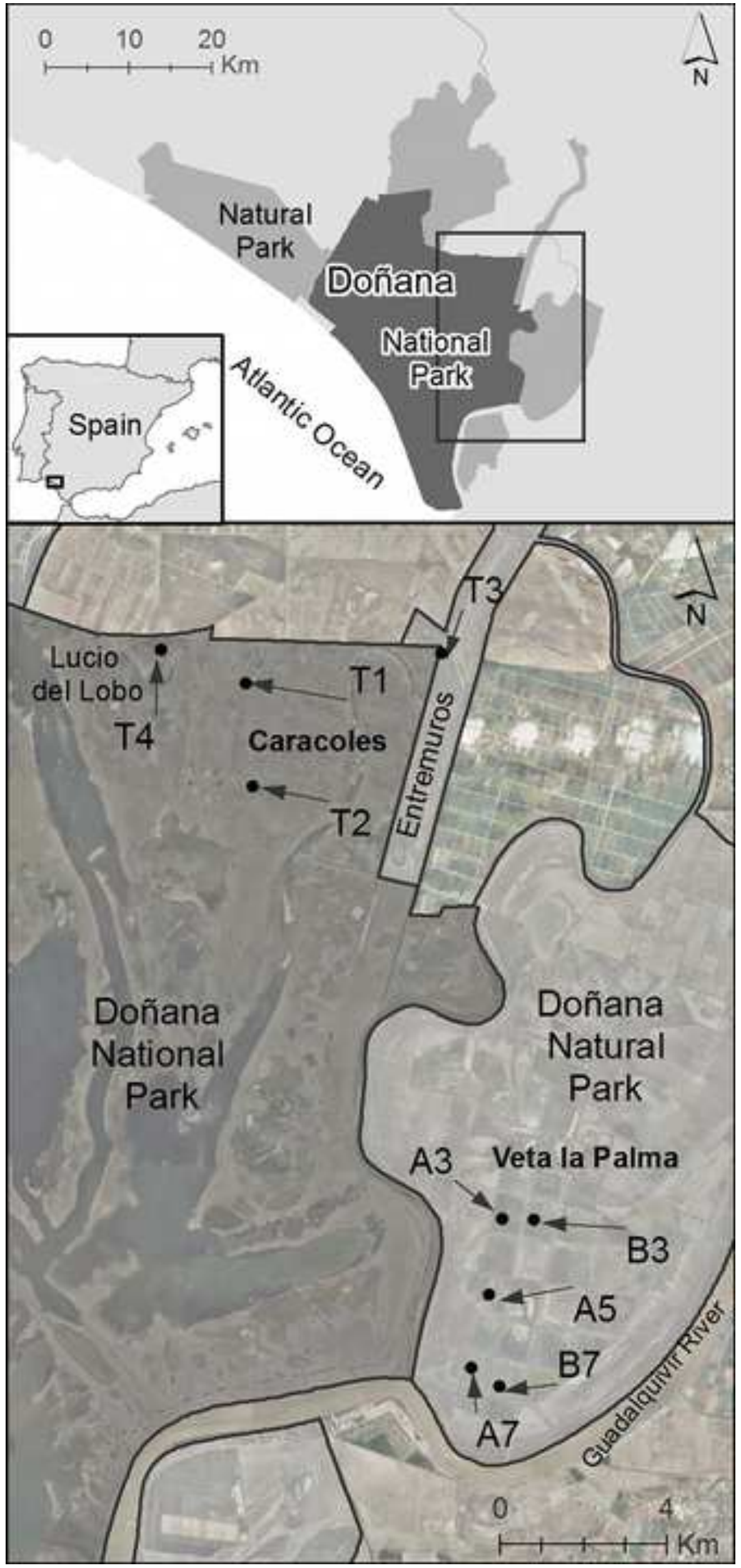




\section{AQ1}

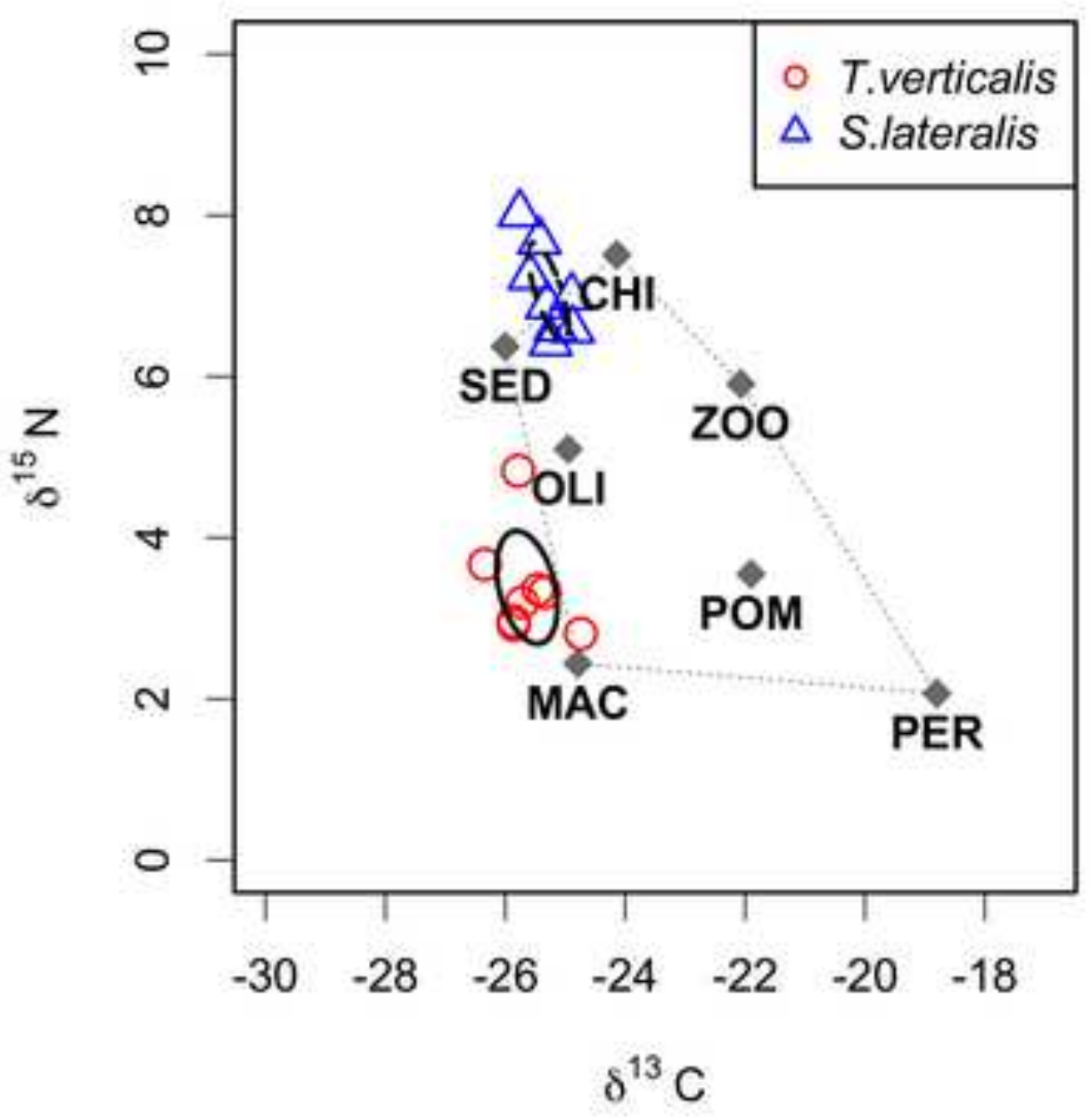

AQ2

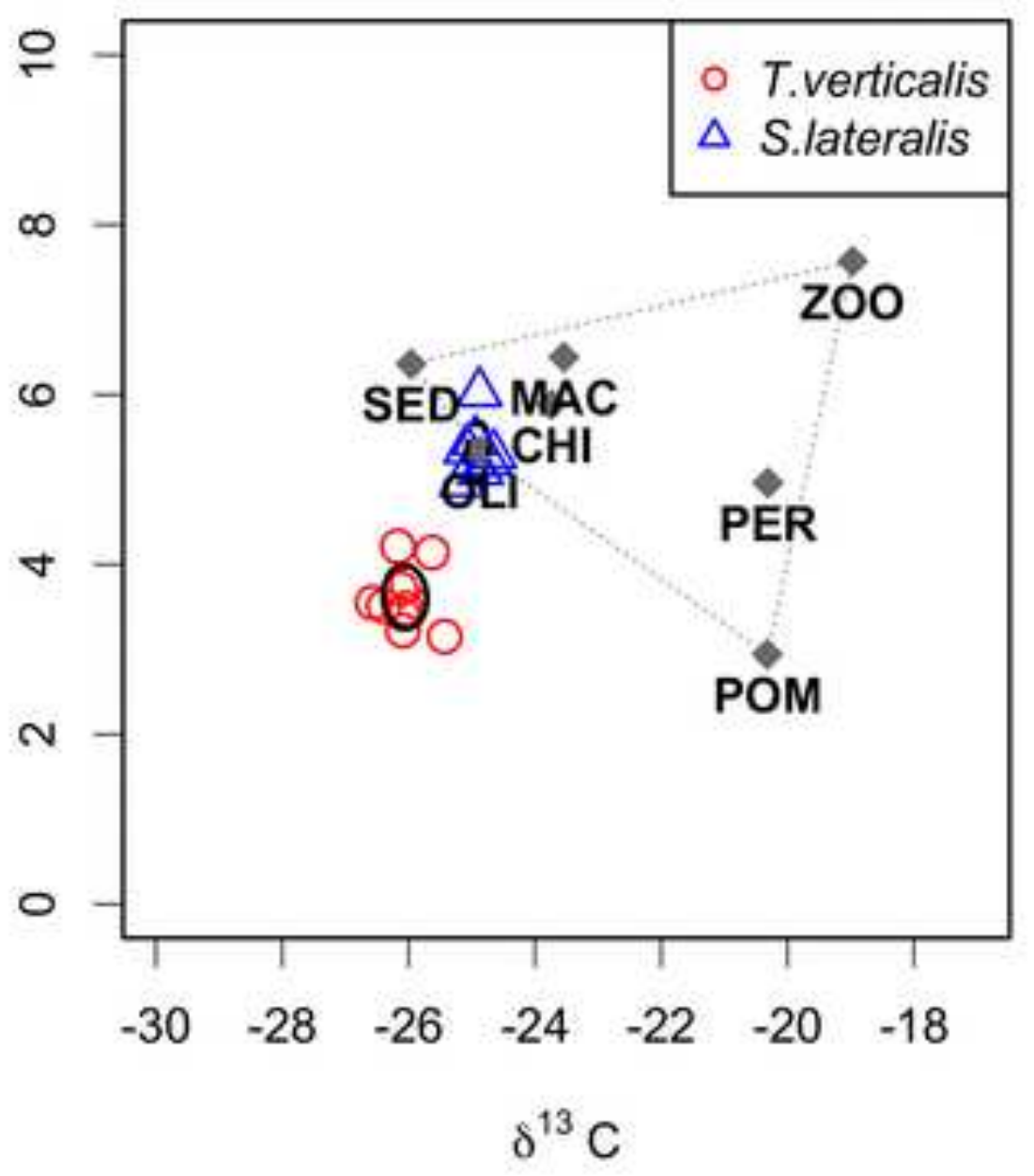


A3

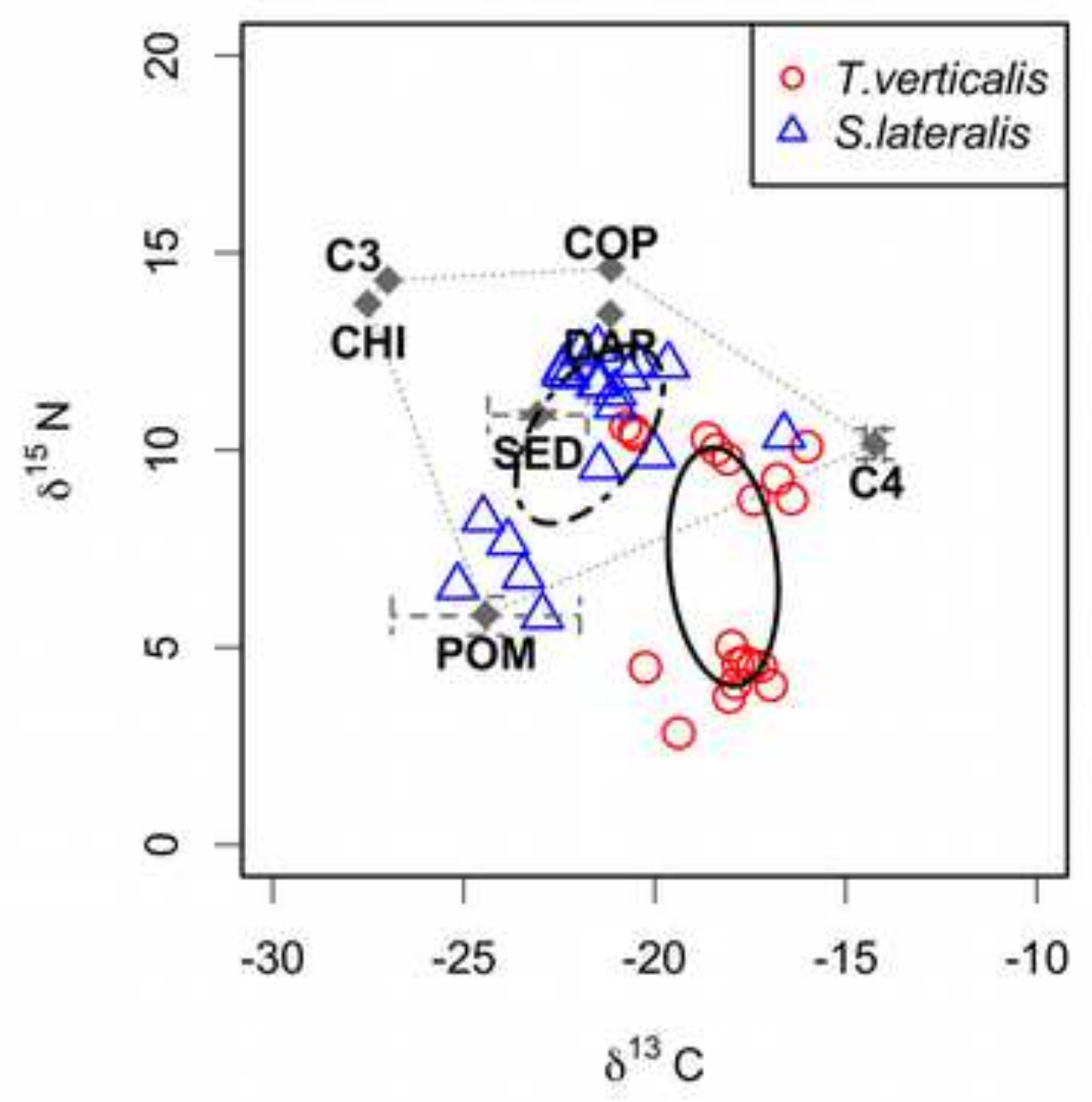

B3

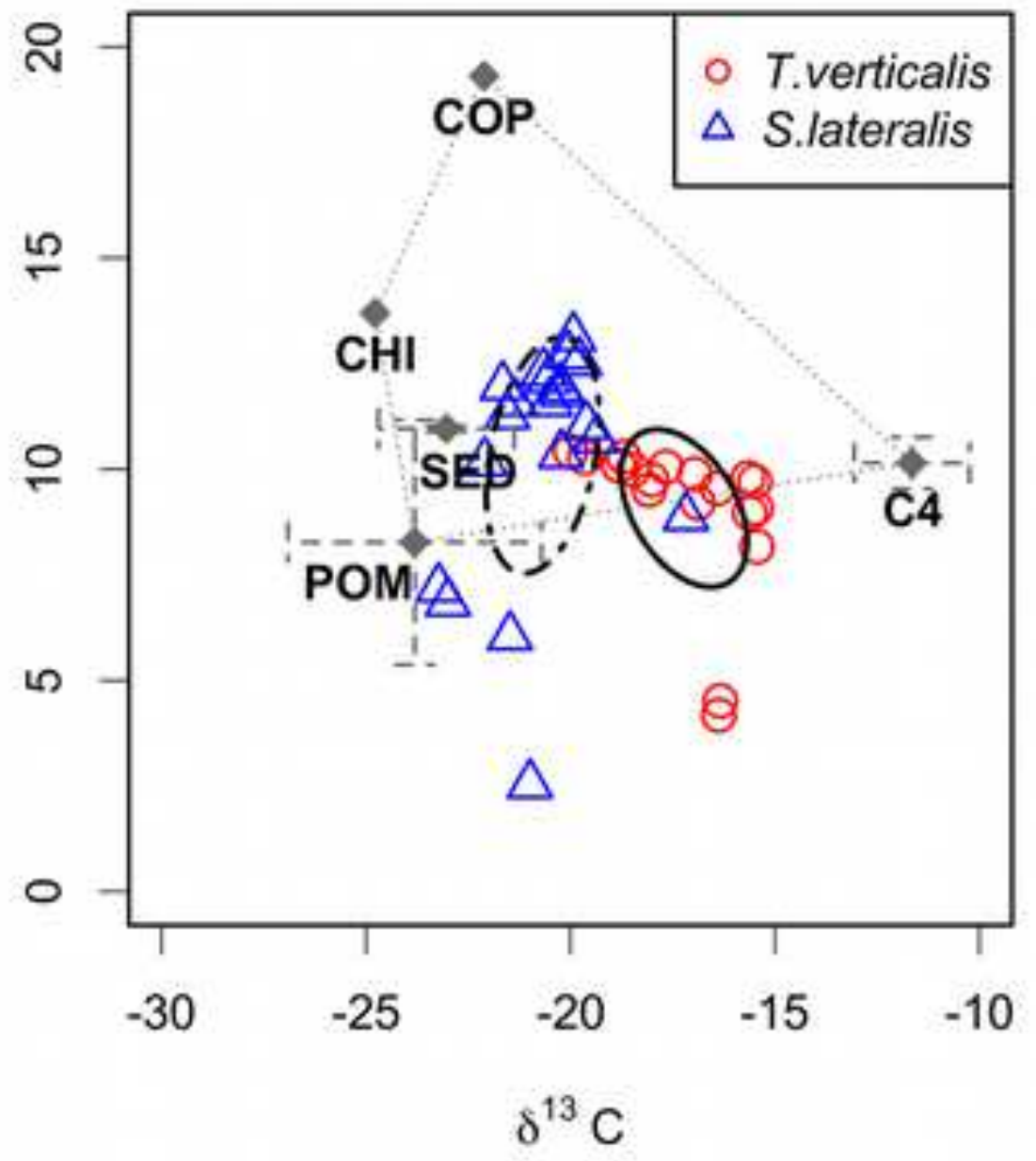


T1
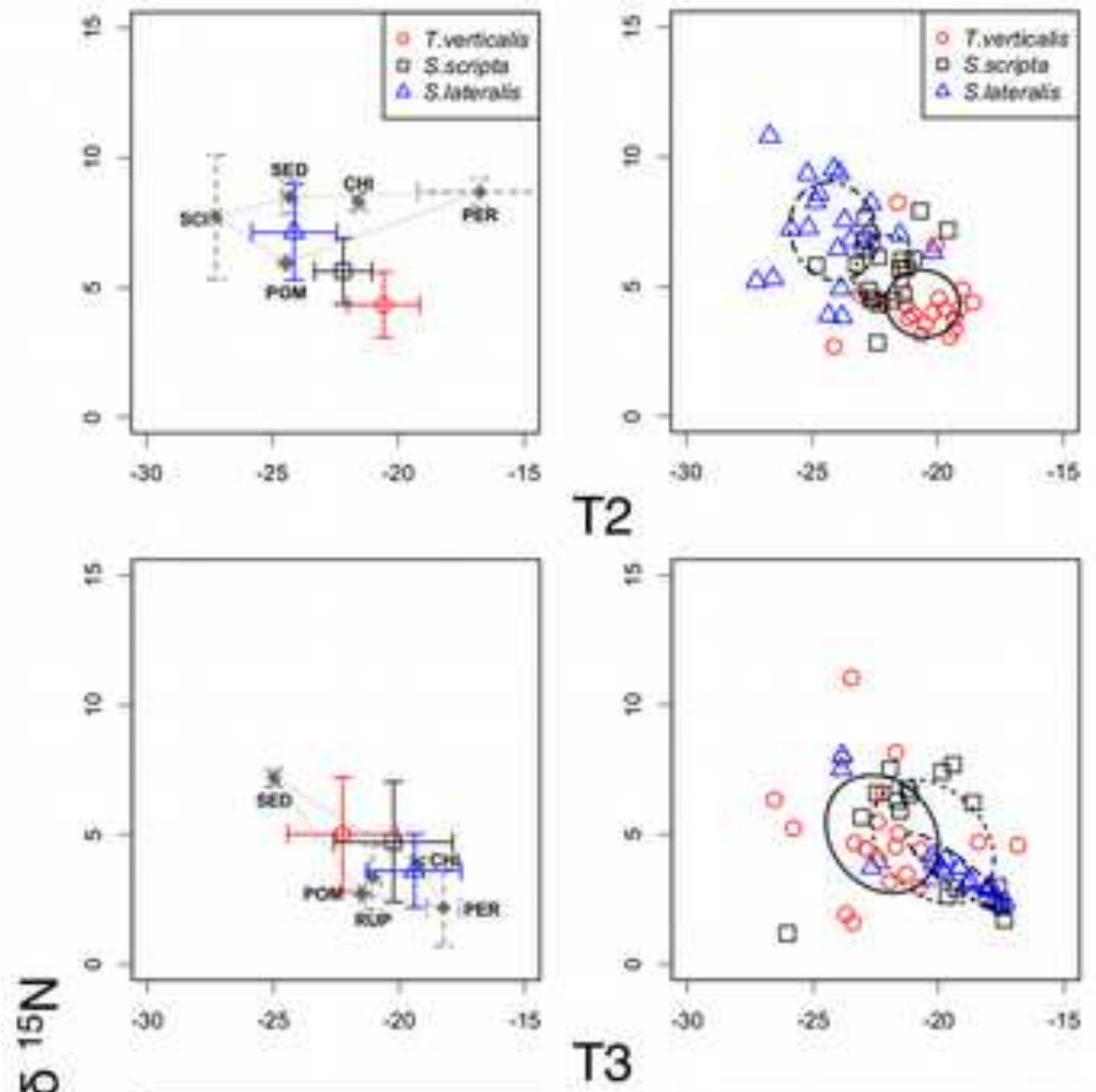

T3
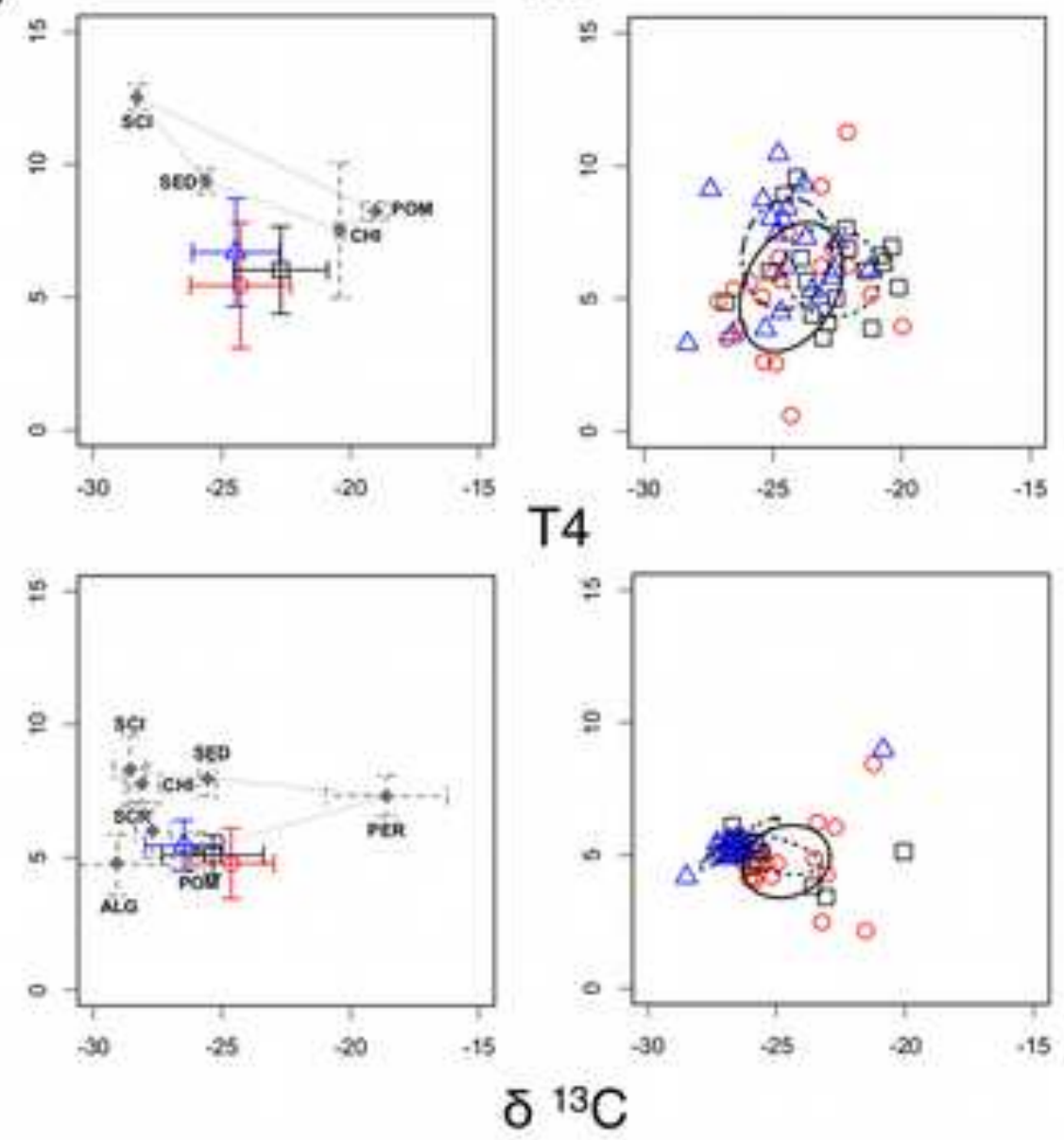
Table 1 Stable isotope values (mean $\pm \mathrm{SD}$ ) and \% of Carbon and Nitrogen (mean $\pm \mathrm{SD}$ ) of $T$. verticalis (TV), S. lateralis (SL) and $S$. scripta (SS) in the aquaria (AQ1, AQ2), permanent ponds (A3, B3) and temporary waters (T1-T4).

\begin{tabular}{lllrrrr}
\hline Sites & Species & $n$ & $\delta{ }^{13} \mathrm{C} \pm \mathrm{SD}$ & $\% \mathrm{C} \pm \mathrm{SD}$ & $\delta{ }^{15} \mathrm{~N} \pm \mathrm{SD}$ & $\% \mathrm{~N} \pm \mathrm{SD}$ \\
\hline AQ1 & TV & 8 & $-25.1 \pm 0.5$ & $48.7 \pm 0.7$ & $5.7 \pm 0.6$ & $11.1 \pm 0.2$ \\
& SL & 8 & $-24.8 \pm 0.3$ & $49.4 \pm 0.9$ & $9.3 \pm 0.6$ & $10.8 \pm 0.2$ \\
\hline AQ2 & TV & 10 & $-25.5 \pm 0.3$ & $46.3 \pm 0.7$ & $5.9 \pm 0.3$ & $11.4 \pm 0.1$ \\
& SL & 8 & $-24.4 \pm 0.2$ & $44.9 \pm 1.7$ & $7.6 \pm 0.3$ & $10.9 \pm 0.1$ \\
\hline A3 & TV & 20 & $-16.7 \pm 1.4$ & $55.8 \pm 1.1$ & $11.4 \pm 2.9$ & $10.6 \pm 0.6$ \\
& SL & 20 & $-21.2 \pm 1.9$ & $55.5 \pm 1.7$ & $12.7 \pm 2.2$ & $10.6 \pm 0.7$ \\
\hline B3 & TV & 18 & $-17.7 \pm 1.5$ & $55.9 \pm 1.9$ & $9.3 \pm 1.8$ & $11.1 \pm 0.7$ \\
& SL & 20 & $-20.2 \pm 1.3$ & $57.3 \pm 1.6$ & $12.6 \pm 2.7$ & $10.8 \pm 0.7$ \\
\hline T1 & TV & 20 & $-20.1 \pm 1.4$ & $47.9 \pm 6.0$ & $6.6 \pm 1.3$ & $12.1 \pm 2.4$ \\
& SL & 21 & $-23.6 \pm 1.7$ & $38.2 \pm 5.9$ & $9.4 \pm 1.8$ & $16.8 \pm 1.8$ \\
& SS & 19 & $-21.6 \pm 1.1$ & $39.2 \pm 1.9$ & $7.9 \pm 1.3$ & $15.5 \pm 1.8$ \\
\hline T2 & TV & 20 & $-21.7 \pm 2.2$ & $40.1 \pm 1.4$ & $7.3 \pm 2.2$ & $14.9 \pm 0.9$ \\
& SL & 23 & $-18.9 \pm 1.9$ & $46.7 \pm 1.8$ & $5.9 \pm 1.4$ & $11.0 \pm 0.4$ \\
& SS & 18 & $-19.8 \pm 2.3$ & $49.3 \pm 2.3$ & $7.0 \pm 2.3$ & $10.6 \pm 1.0$ \\
\hline T3 & TV & 20 & $-23.8 \pm 2.0$ & $39.4 \pm 0.7$ & $7.7 \pm 2.4$ & $15.1 \pm 0.8$ \\
& SL & 20 & $-23.9 \pm 1.8$ & $39.3 \pm 2.1$ & $8.9 \pm 2.6$ & $15.5 \pm 1.1$ \\
& SS & 18 & $-22.2 \pm 1.7$ & $37.5 \pm 4.5$ & $8.3 \pm 2.0$ & $15.7 \pm 1.2$ \\
\hline T4 & TV & 19 & $-24.1 \pm 1.7$ & $49.9 \pm 3.9$ & $7.1 \pm 1.3$ & $10.8 \pm 0.7$ \\
& SL & 18 & $-25.9 \pm 1.5$ & $49.5 \pm 3.7$ & $7.7 \pm 0.9$ & $11.2 \pm 0.5$ \\
& SS & 13 & $-24.9 \pm 2.0$ & $49.6 \pm 1.7$ & $7.4 \pm 0.7$ & $10.6 \pm 0.9$ \\
\hline
\end{tabular}

Local names for these sites are as follows: $\mathrm{T} 1=$ 9N3PP; T2 $=$ AC3; T3 $=$ Entremuros; T4 = Lucio del Lobo (see Frisch et al. 2012 for details). See Fig. 1 for location. 
Table 2 Summary of niche width analyses based on Bayesian tools showing the Isotopic space (SEAc) inhabited by $T$. verticalis (TV), S. lateralis (SL) and S. scripta (SS), the Bayesian probability that the isotopic space (SEAc) of one species was smaller than that of the other species, and the proportional SEAc overlap. Sample sizes $(n)$ are reported for each species in each aquaria (AQ1, AQ2) and temporary ponds (T1-T4). Asterisks indicate significant differences between SEAc values.

\begin{tabular}{|c|c|c|c|c|c|c|c|c|c|c|c|c|}
\hline \multirow[t]{2}{*}{ Sites } & \multicolumn{3}{|c|}{$n$} & \multicolumn{3}{|c|}{$\begin{array}{l}\text { SEAC } \\
\left(\mathbf{\% o}^{2}\right)\end{array}$} & \multicolumn{3}{|c|}{$\begin{array}{c}\text { Bayesian } \\
\text { probability } \\
(\%)\end{array}$} & \multicolumn{3}{|c|}{$\begin{array}{c}\text { SEAC } \\
\text { overlap ( } \%)\end{array}$} \\
\hline & TV & SL & SS & TV & $\mathrm{SL}$ & $\mathrm{SS}$ & $\begin{array}{l}\text { TV- } \\
\text { SL }\end{array}$ & $\begin{array}{l}\text { TV- } \\
\text { SS }\end{array}$ & $\begin{array}{l}\text { SS- } \\
\text { SL }\end{array}$ & $\begin{array}{l}\text { TV- } \\
\text { SL }\end{array}$ & $\begin{array}{l}\text { TV- } \\
\text { SS }\end{array}$ & $\begin{array}{l}\text { SS- } \\
\text { SL }\end{array}$ \\
\hline AQ1 & 8 & 8 & I & 1.04 & 0.43 & I & 32 & I & I & 0 & I & I \\
\hline AQ2 & 10 & 8 & I & 0.19 & 0.40 & I & 52 & I & I & 0 & I & I \\
\hline $\mathrm{T} 1$ & 20 & 21 & 19 & 5.93 & 10.34 & 4.73 & $96^{*}$ & 25 & $99 *$ & 0 & 5 & 4 \\
\hline $\mathrm{T} 2$ & 20 & 23 & 18 & 15.67 & 3.88 & 17.36 & $0^{*}$ & 61 & $0 *$ & 5 & 23 & 15 \\
\hline $\mathrm{T} 3$ & 20 & 20 & 18 & 14.54 & 11.38 & 9.94 & 22 & 12 & 67 & 31 & 24 & 18 \\
\hline $\mathrm{T} 4$ & 19 & 18 & 13 & 7.26 & 1.45 & 4.31 & $0.09 *$ & 10 & $4^{*}$ & 0.16 & 27 & 12 \\
\hline
\end{tabular}


Table $3 \mathrm{P}$ values for comparison of mean centroid position between $T$. verticalis (TV), $S$. lateralis (SL) and $S$. scripta (SS) in the aquaria (AQ1, AQ2), permanent ponds (A3, B3) and temporary ponds (T1-T4) according to the methodology developed by Turner, et al. (2010). Significant differences are indicated by asterisks.

\begin{tabular}{llll}
\hline Sites & \multicolumn{2}{l}{ Species comparison } \\
& TV-SL & TV-SS & SS-SL \\
\hline AQ1 & $0.001^{*}$ & $/$ & $/$ \\
\hline AQ2 & $0.001^{*}$ & $/$ & $/$ \\
\hline A3 & $0.001^{*}$ & $/$ & $/$ \\
\hline B3 & $0.001^{*}$ & $/$ & $/$ \\
\hline T1 & $0.001^{*}$ & $0.001^{*}$ & $0.001^{*}$ \\
\hline T2 & $0.001^{*}$ & $0.008^{*}$ & 0.084 \\
\hline T3 & 0.106 & $0.018^{*}$ & $0.008^{*}$ \\
\hline T4 & $0.001^{*}$ & 0.297 & 0.073 \\
\hline
\end{tabular}




\title{
Journal Name
}

Aquatic Sciences

\section{Title}

Niche partitioning between invasive and native corixids (Hemiptera, Corixidae) in south-west Spain.

\author{
Authors \\ Cristina Coccia ${ }^{1 *}$, Brian Fry ${ }^{2}$, Francisco Ramírez ${ }^{3}$, Luz Boyero ${ }^{1,4,5}$, Stuart E. Bunn², \\ Carmen Diz-Salgado ${ }^{1}$, Mark Walton ${ }^{6}$, Lewis Le Vay ${ }^{6}$ and Andy J. Green ${ }^{1}$ \\ ${ }^{1}$ Department of Wetland Ecology, Doñana Biological Station (EBD-CSIC), Américo \\ Vespucio s/n, 41092 Seville, Spain \\ ${ }^{2}$ Australian Rivers Institute, Griffith University, Nathan, Queensland, Australia, 411 \\ ${ }^{3}$ Department of Biological Conservation, Doñana Biological Station (EBD-CSIC), \\ Américo Vespucio s/n, 41092 Seville, Spain \\ ${ }^{4}$ Present address: Faculty of Science and Technology, University of the Basque Country \\ (UPV/EHU), Leioa, Spain \\ ${ }^{5}$ Present address: IKERBASQUE, Basque Foundation for Science, Bilbao, Spain \\ ${ }^{6}$ Centre for Applied Marine Sciences, Bangor University, Wales, UK \\ *Corresponding author: coccia@ebd.csic.es
}


Online Resource 1 Salinity and Chlorophyll a variation in temporary (T) and permanent waterbodies (A-B) across seasons.

\begin{tabular}{llll}
\hline Sites & Season & Chl $a\left(\mu \mathrm{gl}^{-1}\right)$ & Salinity (psu) \\
\hline T1 & summer & 36.4 & 7.6 \\
T2 & summer & 105.5 & 15.9 \\
T3 & summer & 44.6 & 8.7 \\
T4 & summer & 76.7 & 5.4 \\
\hline A3 & summer & 55.5 & 9.1 \\
B3 & summer & 145.5 & 9.3 \\
A7 & summer & 155.0 & 19.8 \\
B7 & summer & 135 & 18.6 \\
A5 & summer & 157.0 & 8.7 \\
\hline A7 & winter & 23.7 & 18.3 \\
B7 & winter & 53.7 & 11.6 \\
A5 & winter & 15.5 & 10.9 \\
\hline
\end{tabular}




\title{
Journal Name
}

Aquatic Sciences

\section{Title}

Niche partitioning between invasive and native corixids (Hemiptera, Corixidae) in south-west Spain.

\author{
Authors \\ Cristina Coccia ${ }^{1 *}$, Brian Fry ${ }^{2}$, Francisco Ramírez ${ }^{3}$, Luz Boyero ${ }^{1,4,5}$, Stuart E. Bunn², \\ Carmen Diz-Salgado ${ }^{1}$, Mark Walton ${ }^{6}$, Lewis Le Vay ${ }^{6}$ and Andy J. Green ${ }^{1}$ \\ ${ }^{1}$ Department of Wetland Ecology, Doñana Biological Station (EBD-CSIC), Américo \\ Vespucio s/n, 41092 Seville, Spain \\ ${ }^{2}$ Australian Rivers Institute, Griffith University, Nathan, Queensland, Australia, 411 \\ ${ }^{3}$ Department of Biological Conservation, Doñana Biological Station (EBD-CSIC), \\ Américo Vespucio s/n, 41092 Seville, Spain \\ ${ }^{4}$ Present address: Faculty of Science and Technology, University of the Basque Country \\ (UPV/EHU), Leioa, Spain \\ ${ }^{5}$ Present address: IKERBASQUE, Basque Foundation for Science, Bilbao, Spain \\ ${ }^{6}$ Centre for Applied Marine Sciences, Bangor University, Wales, UK \\ *Corresponding author: coccia@ebd.csic.es
}


Online Resource 2 Sampling methodology used across temporary and permanent waterbodies.

\begin{tabular}{|c|c|}
\hline Species & Sampling methods \\
\hline Corixids (adults and juveniles) & D-framed pond net $(500 \mu \mathrm{m}$ mesh; $16 \times 16 \mathrm{~cm})$ \\
\hline Benthos & $\begin{array}{l}\text { D-framed pond net }(500 \mu \mathrm{m} \text { mesh; } 16 \times 16 \mathrm{~cm}) \\
\text { Cylindrical }\left(32 \mathrm{~cm}^{2}\right) \text { cores. } \\
\text { Box }\left(240 \mathrm{~cm}^{2}\right) \text { cores. }\end{array}$ \\
\hline Zooplankton & $\begin{array}{l}\text { Tows }(200 \mu \mathrm{m} \text { and } 500 \mu \mathrm{m} \text { sizes }) \text {. } \\
\text { Concentrated in laboratory on a } 64 \mu \mathrm{m} \text { mesh }\end{array}$ \\
\hline Mysidacea & $\begin{array}{l}\text { Fixed traps (Fyke type, funnel-mouthed bags } \\
\text { trap) with three mesh sizes: } 2 \mathrm{~mm}, 5 \mathrm{~mm} \text { and } 10 \\
\mathrm{~mm} \text {. }\end{array}$ \\
\hline Macrophytes & $\begin{array}{l}\text { Collected by hand from the water's edge and in } \\
\text { the lagoon }\end{array}$ \\
\hline $\begin{array}{l}\text { Epiphyton (periphyton on } \\
\text { macrophytes) }\end{array}$ & $\begin{array}{l}\text { Submerged part of plants were brushed with a } \\
\text { toothbrush, then vigorously shaked in distilled } \\
\text { water }\end{array}$ \\
\hline $\begin{array}{l}\text { Epilithon (periphyton on hard } \\
\text { substrates) }\end{array}$ & $\begin{array}{l}\text { Jar lids were brushed with a toothbrush, then } \\
\text { vigorously shaked in distilled water }\end{array}$ \\
\hline Sediments (i.e. epipelon) & Benthic corer (top $5 \mathrm{~mm}$ ) \\
\hline
\end{tabular}




\title{
Journal Name
}

Aquatic Sciences

\section{Title}

Niche partitioning between invasive and native corixids (Hemiptera, Corixidae) in south-west Spain.

\author{
Authors \\ Cristina Coccia ${ }^{1 *}$, Brian Fry ${ }^{2}$, Francisco Ramírez ${ }^{3}$, Luz Boyero ${ }^{1,4,5}$, Stuart E. Bunn², \\ Carmen Diz-Salgado ${ }^{1}$, Mark Walton ${ }^{6}$, Lewis Le Vay ${ }^{6}$ and Andy J. Green ${ }^{1}$ \\ ${ }^{1}$ Department of Wetland Ecology, Doñana Biological Station (EBD-CSIC), Américo \\ Vespucio s/n, 41092 Seville, Spain \\ ${ }^{2}$ Australian Rivers Institute, Griffith University, Nathan, Queensland, Australia, 411 \\ ${ }^{3}$ Department of Biological Conservation, Doñana Biological Station (EBD-CSIC), \\ Américo Vespucio s/n, 41092 Seville, Spain \\ ${ }^{4}$ Present address: Faculty of Science and Technology, University of the Basque Country \\ (UPV/EHU), Leioa, Spain \\ ${ }^{5}$ Present address: IKERBASQUE, Basque Foundation for Science, Bilbao, Spain \\ ${ }^{6}$ Centre for Applied Marine Sciences, Bangor University, Wales, UK \\ *Corresponding author: coccia@ebd.csic.es
}


Online Resource 3 Standards used at UC Davis and at LIE laboratory. The internal standards used by each laboratory (labelled in italics) include measured values. These internal standards have been previously calibrated against international standards (labelled in normal font).

$\boldsymbol{\delta}^{13} \mathrm{C}\left(\%\right.$ VPDB) $\quad \% \mathrm{C} \quad \boldsymbol{\delta}^{15} \mathrm{~N}$ (\%oAir) $\quad \% \mathrm{~N}$

UC Davis

Bovine Liver

$-21.69$

7.72

Nylon

$-27.81$

40.81

$-9.77$

Peach leaves

$-26.12$

46.18

1.95

2.88

IAEA-N-1 Ammonium sulphate

$+0.4 \pm 0.2$

IAEA-N-2 Ammonium sulphate

$+20.3 \pm 0.2$

IAEA-N-3 Potassium nitrate

$+4.7 \pm 0.2$

USGS-40 L Glutamic Acid

$-26.39 \pm 0.04$

$-4.5 \pm 0.1$

USGS-41 L Glutamic Acid

$+37.63 \pm 0.05$

$+47.6 \pm 0.2$

LIE (EBD-CSIC)

EBD-23 Cow Horn

$-22.49 \pm 0.12$

$9.94 \pm 0.14$

LIE-BB Whale Baleen

$-22.48$

9.92

LIE-PA Feathers of Razorbill

$-15.72 \pm 0.08$

$16.55 \pm 0.2$

LIE-P 22 Protein

$26.98 \pm 0.13$

5.94

EEZ-20 Saccharose

$-12.26$

IAEA-600 Caffeine

$-27.77 \pm 0.04$

$+1.0 \pm 0.2$

IAEA-N-2 Ammonium sulphate

$+20.3 \pm 0.2$

USGS-40 L Glutamic Acid

$-26.39 \pm 0.04$

$-4.5 \pm 0.1$ 


\title{
Journal Name
}

Aquatic Sciences

\section{Title}

Niche partitioning between invasive and native corixids (Hemiptera, Corixidae) in south-west Spain.

\author{
Authors \\ Cristina Coccia ${ }^{1 *}$, Brian Fry ${ }^{2}$, Francisco Ramírez ${ }^{3}$, Luz Boyero ${ }^{1,4,5}$, Stuart E. Bunn², \\ Carmen Diz-Salgado ${ }^{1}$, Mark Walton ${ }^{6}$, Lewis Le Vay ${ }^{6}$ and Andy J. Green ${ }^{1}$ \\ ${ }^{1}$ Department of Wetland Ecology, Doñana Biological Station (EBD-CSIC), Américo \\ Vespucio s/n, 41092 Seville, Spain \\ ${ }^{2}$ Australian Rivers Institute, Griffith University, Nathan, Queensland, Australia, 411 \\ ${ }^{3}$ Department of Biological Conservation, Doñana Biological Station (EBD-CSIC), \\ Américo Vespucio s/n, 41092 Seville, Spain \\ ${ }^{4}$ Present address: Faculty of Science and Technology, University of the Basque Country \\ (UPV/EHU), Leioa, Spain \\ ${ }^{5}$ Present address: IKERBASQUE, Basque Foundation for Science, Bilbao, Spain \\ ${ }^{6}$ Centre for Applied Marine Sciences, Bangor University, Wales, UK \\ *Corresponding author: coccia@ebd.csic.es
}


Online Resource 4 Dual-isotope food web diagram within three permanent ponds (A5, A7 and B7) illustrating isotopic differences in T. verticalis adults and nymphs during winter.
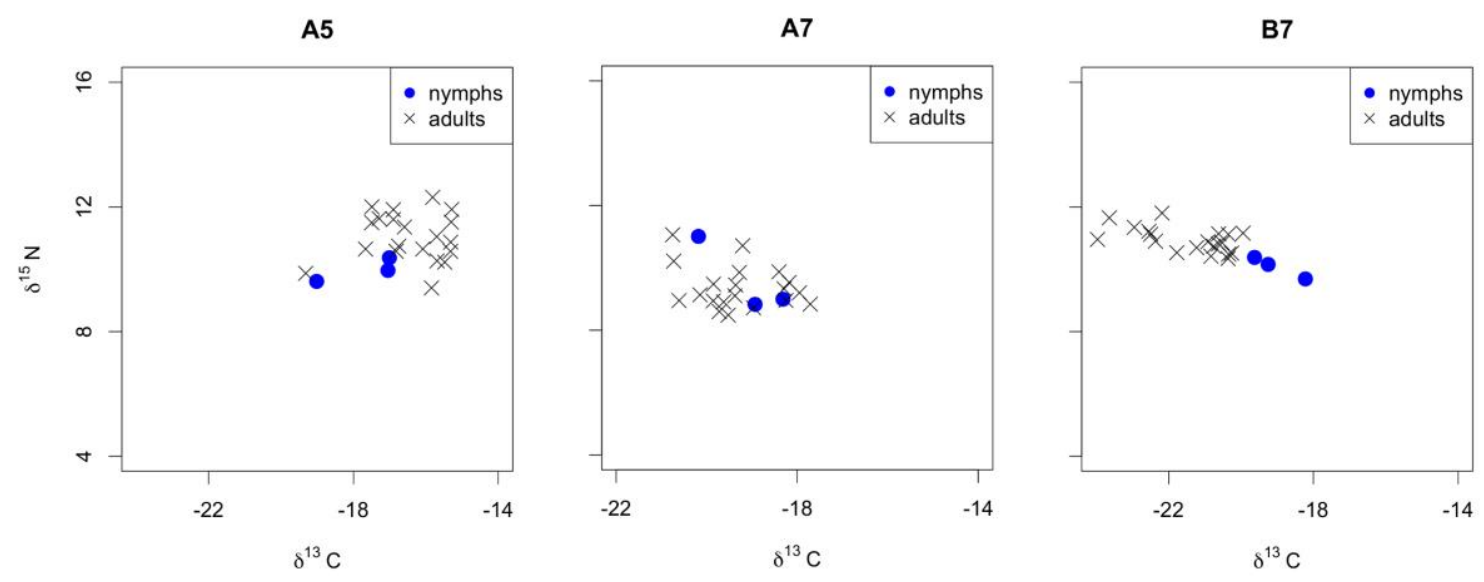


\title{
Journal Name
}

Aquatic Sciences

\section{Title}

Niche partitioning between invasive and native corixids (Hemiptera, Corixidae) in south-west Spain.

\author{
Authors \\ Cristina Coccia ${ }^{1 *}$, Brian Fry $^{2}$, Francisco Ramírez ${ }^{3}$, Luz Boyero ${ }^{1,4,5}$, Stuart E. Bunn ${ }^{2}$, \\ Carmen Diz-Salgado ${ }^{1}$, Mark Walton ${ }^{6}$, Lewis Le Vay ${ }^{6}$ and Andy J. Green ${ }^{1}$
}

${ }^{1}$ Department of Wetland Ecology, Doñana Biological Station (EBD-CSIC), Américo Vespucio s/n, 41092 Seville, Spain

${ }^{2}$ Australian Rivers Institute, Griffith University, Nathan, Queensland, Australia, 411

${ }^{3}$ Department of Biological Conservation, Doñana Biological Station (EBD-CSIC), Américo Vespucio s/n, 41092 Seville, Spain

${ }^{4}$ Present address: Faculty of Science and Technology, University of the Basque Country (UPV/EHU), Leioa, Spain

${ }^{5}$ Present address: IKERBASQUE, Basque Foundation for Science, Bilbao, Spain

${ }^{6}$ Centre for Applied Marine Sciences, Bangor University, Wales, UK

*Corresponding author: coccia@ebd.csic.es 
Online Resource 5 Dual-isotope food web diagram of three permanent ponds (A5, A7 and B7) illustrating isotopic seasonal and spatial variation in T. verticalis and common food web components: $\mathrm{CHI}=$ chironomids; $\mathrm{PER}=$ periphyton; $\mathrm{POM}=$ particulate organic matter; MYS $=$ Mesopodopsis slabberi; $\mathrm{SED}=$ sediments.
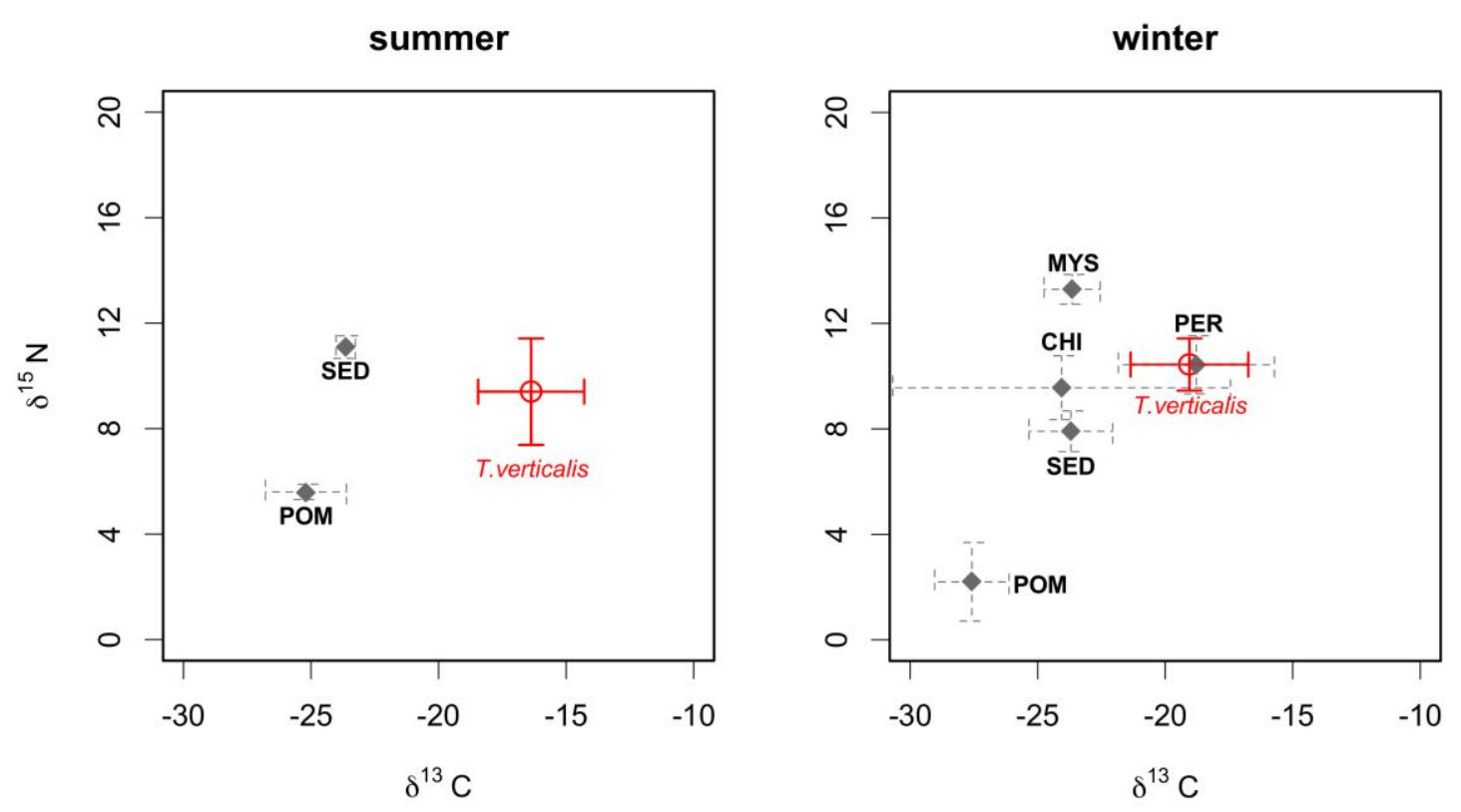


\section{Journal Name \\ 2 Aquatic Sciences}

3

4 Title

5 Niche partitioning between invasive and native corixids (Hemiptera, Corixidae) in south-west 6 Spain.

8 Authors

9 Cristina Coccia ${ }^{1 *}$, Brian Fry ${ }^{2}$, Francisco Ramírez ${ }^{3}$, Luz Boyero ${ }^{1,4,5}$, Stuart E. Bunn ${ }^{2}$, Carmen

10 Diz-Salgado ${ }^{1}$, Mark Walton ${ }^{6}$, Lewis Le Vay ${ }^{6}$ and Andy J. Green ${ }^{1}$

$11{ }^{1}$ Department of Wetland Ecology, Doñana Biological Station (EBD-CSIC), Américo 12 Vespucio s/n, 41092 Seville, Spain

$13{ }^{2}$ Australian Rivers Institute, Griffith University, Nathan, Queensland, Australia, 4111

$14{ }^{3}$ Department of Biological Conservation, Doñana Biological Station (EBD-CSIC), Américo

15 Vespucio s/n, 41092 Seville, Spain

$16{ }^{4}$ Present address: Faculty of Science and Technology, University of the Basque Country 17 (UPV/EHU), Leioa, Spain

$18{ }^{5}$ Present address: IKERBASQUE, Basque Foundation for Science, Bilbao, Spain

$19{ }^{6}$ Centre for Applied Marine Sciences, Bangor University, Wales, UK 20

$21 *$ Corresponding author: coccia@ebd.csic.es 
34 Online Resource 6 Range of stable isotope values of source items $(n=3)$ in 4 temporary 35 waters: PER = periphyton; POM = particulate organic matter; SCI = Scirpus $\mathrm{sp}$; RUP = 36 Ruppia sp.; $\mathrm{SCR}=$ Scirpus sp. root; $\mathrm{ALG}=$ filamentous algae; $\mathrm{CHI}=$ chironomids; $\mathrm{SED}=$ 37 sediments.

\begin{tabular}{llcc}
\hline \multirow{2}{*}{ Sites } & & \multicolumn{2}{c}{ Range } \\
\cline { 2 - 4 } T1 & PEurce & \multicolumn{1}{c}{$\boldsymbol{\delta}^{13} \mathrm{C}$} & $\boldsymbol{\delta}^{15} \mathrm{~N}$ \\
\hline & POM & -24.1 to -14.1 & 8.1 to 9.0 \\
& SCI & -27.4 to -27.3 & 5.8 to 6.0 \\
& CHI & -21.8 to -21.4 & 7.0 to 9.7 \\
& SED & -24.7 to -24.1 & 7.8 to 9.0 \\
\hline T2 & PER & -18.6 to -17.5 & 1.2 to 3.9 \\
& POM & -21.6 to -21.4 & 2.7 to 2.8 \\
& RUP & -21.3 to -20.7 & 2.3 to 4.7 \\
& CHI & -19.5 to -19.1 & 3.7 to 4.2 \\
& SED & -25.1 to -24.8 & 6.9 to 7.5 \\
\hline T3 & POM & -19.4 to -18.5 & 7.9 to 8.6 \\
& SCI & -28.3 to -28.2 & 12.0 to 13.0 \\
& CHI & -20.5 to -20.2 & 4.6 to 9.0 \\
& SED & -25.8 to -25.5 & 9.5 to 9.8 \\
\hline T4 & PER & -21.0 to -16.3 & 6.7 to 8.1 \\
& POM & -26.1 to -25.7 & 4.7 to 6.0 \\
& ALG & -31.3 to -26.9 & 3.9 to 6.1 \\
& SCI & -29.3 to -28.1 & 7.3 to 9.8 \\
& SCR & -28.5 to -27.1 & 4.9 to 6.9 \\
& CHI & -28.6 to -27.3 & 7.2 to 8.5 \\
& SED & -25.9 to -25.2 & 7.6 to 8.7 \\
\hline & & &
\end{tabular}

